\title{
Benzerlik ve farklılıklarıyla çocukluk çağında DEHB ve OSB: Bir gözden geçirme çalışması
}

\author{
Similarities and differences in childhood ADHD and ASB: \\ A review study
}

\section{Makale Geçmişi \\ Geliş : :16 Ocak 2020 \\ Düzeltme : 26 Mart 2020 \\ Kabul : 27 Mart 2020}

Makale Türü

Derleme Makale

\section{Article History}

Received : 16 January 2020

Revised : 26 March 2020

Accepted : 27 March 2020

\section{Article Type}

Review Article
Gamze ŞEN ${ }^{1}$
Öz: Otizm Spektrum Bozukluğu (OSB) ve Dikkat Eksikliği Hiperaktivite Bozukluğu (DEHB), son yıllarda tüm dünyada ve ülkemizde yaygınlığı hızla artan çocukluk çağ1 nöro-gelişimsel bozukluklardır. Mental Bozuklukların Tanısal ve Sayımsal El Kitabının son sayısı olan DSM-IV'te (2013) son dönemdeki güncel değişiklikle ilişkili olarak DEHB ve OSB eş tanısı konulabilir hale gelmiştir. Bu çalışmanın birinci amacı her iki bozukluğun da, eş tanı ve ayırt edici tanısal özelliklerin belirlenmesi amacıyla, benzer ve farklı yönleriyle genetik, bilişsel, nörolojik, davranışsal, sosyal ve duygusal yönleriyle incelenmesidir. İkinci olarak da her iki bozukluk açısından güncel tedavi yaklaşımları ve bu yaklaşımların etkililiğine ilişkin çalışmaların sunulması ve alanyazının gözden geçirilmesidir. Bu kapsamda DSM-IV'teki değişimi anlayabilmek adına özellikle son yirmi yıldaki her iki bozukluğu karşılaştıran çalışmaların derlemesi yapılmıştır. Çalışmamız sonucunda elde edilen bulgular değerlendirildiğinde her iki bozukluğun etiyolojisindeki benzerliğin, eş tanı ve ayırt edici tanılara temel oluşturan değişkenlerin aynı çalışmada karşılaştırmalı olarak incelenmesiyle daha iyi anlaşılabileceği söylenebilir. Çalışmamız kapsamında yapılan incelemeler sonucunda tedavi yaklaşımı, toplumsal farkındalık ve sosyal politikalar geliştirilmesine yönelik öneriler sunularak çalışmamız tamamlanmıştır.

Anahtar Kelimeler: Otizm spektrum bozukluğu, Dikkat eksikliği hiperaktivite bozukluğu, gözden geçirme

\begin{abstract}
Autism Spectrum Disorder (ASD) and Attention Deficit Hyperactivity Disorder (ADHD) are childhood neurodevelopmental disorders which prevalence is increasing rapidly all over the world and in our country in recent years. In the latest issue of the Diagnostic and Statistical Manual of Mental Disorders DSM-IV (2013) has increased the interest in ADHD and ASD. Recently, ADHD and ASD have been co-diagnosed in relation to the current change in the recent change. The aim of this study is the examination of both disorders with similar and different characteristics aspects of ASD and ADHD with genetic, cognitive, neurological, behavioral, social and emotional aspects, firstly. Secondly, presenting the current treatment approaches in both disorders and the effectiveness of these approaches and reviewing the literature. In this context, in order to understand the recent years changes in DSMIV, especially the studies comperaing boht disorders focus on the last ten years have been compiled. When the findings obtained as a result of our study are evaluated, it can be said that the similarity in the etiology of both disorders can be better understood by comparing the variables that form the basis of comorbidity and differential diagnosis in the same study. As a result of the investigations, suggestions for treatment approach, social awareness and social policy development were presented and our study was completed.
\end{abstract}

Keywords: Autism spectrum disorder, Attention deficit hyperactivity disorder, Review

DOI: $10.24130 /$ eccd-jecs. 1967202041218

\begin{abstract}
Başlica Yazar:
${ }^{1}$ Gamze Şen, Arș. Gör. Dr., Necmettin Erbakan Üniversitesi, SBBF Psikoloji Bölümü, Meram, Konya. Eposta: senngamze@gmail.com ORCID: https://orcid.org/0000-0002-7698-3256
\end{abstract}




\section{SUMMARY}

\section{Introduction}

Autism Spectrum Disorder (ASD) and Attention Deficit Hyperactivity Disorder (ADHD) are childhood neurodevelopmental disorders which prevalence is increasing rapidly all over the world and in our country in recent years. Studies suggesting that ADHD patients have high levels of ASD symptoms (Grzadzinski et al., 2011; Mulligan et al., 2009) have led to the emergence of a growing group of researchers advocating the view that there is a significant overlap between the two conditions clinically. In the latest Diagnostic and Statistical Manual of Mental Disorders (DSM-IV) has increased the interest in ADHD and ASD. Recently, ADHD and ASD have been comorbid in relation to the current change in the recent change. In this study, based on the current changes in DSM-IV, both disorders are discussed in similar and different aspects in terms of genetic, cognitive, neurological, behavioral, social and emotional aspects, and the advantages and disadvantages of the current situation are discussed. Finally, current treatment approaches and studies on the effectiveness of these approaches are presented. In this context, in order to understand the recent years changes in DSM-IV, especially the study focus on the last ten years have been compiled. There are studies suggesting that there are some similarities between the two types of disability at the etiological and clinical level in studies that qualitatively examine the relationship between ADHD and ASD, as well as studies claiming the opposite and pointing to differences. Within the framework of these similarity findings, it was thought that some of the symptoms of ASD and ADHD were very close to each other, and even two deficiencies could be comorbidity (Sinzig, Walter and Doepfner 2009). On the other hand, the main problem with the recognition of ASD and ADHD in the clinic is controversially related to differential diagnosis (Cortese, 2016). While both disorders were included in the title of 'diffused developmental disorder' in DSM-IV, in DSMIV this diagnostic name was completely removed, and the name of the diagnosis group was changed to the content of the diagnosis and the criteria for diagnosis and decided to be included in a new title called 'neurodevelopmental disorders'. It is also expected that some determinants added to the diagnosis will be coded for another neurodevelopmental, mental or behavioral disorder, and whether it is related to a known medical or genetic condition, or an environmental factor (American Psychiatric Association, 2013). In recent years, it is understood that both ASD and ADHD cannot be explained only with genetic features. Contrary to the view that emphasizes the genetic transition of autism, some researches in recent years emphasize some processes during and after birth. When the prenatal period is considered, the view that adopts the role of immune system incompatibility between mother and fetus in autism spectrum disorder has been determined that in some of the cases diagnosed with autism, the baby's lymphocytes (immune and regulatory) 
react to the mother antibodies (Vargas, Nascimbene, Krishnan, Zimmerman ve Pardo, 2015). For this reason, it is considered that it will be appropriate to examine both disorders starting from prenatal period and postpartum period and throughout life. Both disorders should be examined as an insufficiency based on neurobiological origins in the early stages of development, resulting from a neurodevelopmental interruption by the interaction of environmental and genetic factors (Sonuga-Barke and Halperin, 2010). Additioanlly, it is thought that the effects of environmental factors in individuals diagnosed with ADHD and ASD can be best understood by observing behavioral processes by knowing genetic and neurological processes. While working to understand of autism spectrum disorder and attention deficit hyperactivity disorders, it was understood that it was necessary to work as a source of social and emotional support and in collaboration with the family and the teacher. It is emphasized that teacher and family support will help children to cope with difficulties and play an important role on their upbringing as self-sufficient adults (Öztürk, 2015). Interaction of many factors has an important role in understanding both attention deficit and hypercativity disorder and autism spectrum disorder and the interaction of these factors is very important in their treatment. Therefore, behavioral treatments are applied to both disorders in addition to drug treatment. In the last three years, a series of meta-analysis studies by the European Group of ADHD Guidelines (EGG) was conducted some studies that have included dietary interventions, behavioral interventions, cognitive training, and neurofeedback (a learning strategy that helps one change their brainwaves), addressing the efficacy of different non-pharmacological treatments for ADHD.

\section{Conclusion and Discussion}

In this study, when the behavioral, cognitive, neurological, genetic, social, emotional and developmental findings are evaluated, it is thought that the similarity in the etiology of ADHD and ASD is due to the fact that most of the studies indicating comorbidity were cross-sectional. However, it is seen that studies that integrate neurological findings and clinical observation should be given more attention, participants are homogeneously distributed, and double-blind, placebo controlled, longitudinal or mixed design studies are needed. In the literature, studies investigating the relationship between two deficiencies carried out on children were mostly conducted with the child's family. However, it is thought that the studies to be conducted with more comprehensive and evidence-based methods will allow different impressions and observations to be combined with these children's teachers, siblings and friends (Akbaş, Karabekiroğlu, Pazvantoğlu and Böke, 2009). Considering that the relationship between both disorders is at a level that can be comorbid, patterns combining cross-sectional and longitudinal studies comparing individuals with ASD, ADHD and ASD-ADHD can be used to make the process more efficient. In addition to increasing 
the diagnostic and therapeutic findings through academic studies, social studies at the social level are another important step. 


\section{GİRIŞ}

Otizm Spektrum Bozukluğu (OSB) ile Dikkat Eksikliği ve Hiperaktivite Bozukluğu (DEHB), Mental Bozuklukların Tanısal ve Sayımsal El Kitabının son sayısında (DSM-IV) nöro-gelişimsel yetersizlikler başlığı adı altında yer almaktadır (Amerikan Psikiyatri Birliği (APA), 2013). Dikkat Eksikliği Hiperaktivite Bozukluğu çocukluk döneminde tanımlanan, birçok alanda yetersizlik ile kendini gösteren, ergenlik ve erişkinlikte de belirtilerin bir kısmının değişime uğramasıyla birlikte yaşam boyu süregiden bir rahatsızlıktır. Bu tanıyla birlikte kişilerin akademik yaşamları başta olmak üzere, aile yaşamı, sosyal ilişkileri ve benlik saygısı üzerine çeşitli olumsuz yaşantılar deneyimlenebilmektedir. Ayrıca bu tanıya pek çok psikolojik ve psikiyatrik sorun da eşlik edebilmektedir. Bireyin yaşamındaki yaygın olumsuz etkileri nedeniyle DEHB önemli ruh sağlığı sorunlarından bir haline gelmiştir (Sürücü, 2016). Otizm ise erken çocuklukta başlayan, yaşam boyu devam eden sosyal alanda ve iletişim alanlarında yaşanan güçlükler, gecikmeler ve rahatsızlı̆̆a özgü gelişimsel sapmalar ile karakterize edilmektedir (Amerikan Psikiyatri Birliği, 2015). Yaşam boyu devam eden belirtiler gösteren otizm de sosyal ilişkiler kuramama temelinde yaşanan güçlüklere, akademik ve aile yaşamını da eşlik ederken, DEHB'na göre tablonun biraz daha ağır olduğu bilinmektedir (Cortese, 2016)

Geçtiğimiz ylllarda görülme sıklıklarındaki artışa paralel olarak, ADHD ile OSB arasındaki ilişki, hem klinik hem de araştırma alanında ilgi odağı olmuştur (Antshel, Zhang-James ve Faraone, 2013). DSM IV'ün geçerli olduğu ve DSM-IV'in yayınlandığı son yıllarda otizm spektrum bozukluk olan çocuklarda dikkat eksikliği ve hiperaktivitenin birlikte görüldüğü bulgusuna ulaşan araştırmalar alanyazında artmıştır (Ames ve White, 2011; Rao ve Landa, 2014). DEHB tanısı alanların da klinik olarak yüksek OSB semptom seviyeleri gösterdiklerine ilişkin çalışmalar (Grzadzinski vd., 2011; Mulligan vd., 2009) klinik olarak iki durum arasında önemli bir örtüşme olduğunu görüşünü savunan ve giderek artan bir araştırma grubunun doğmasına neden olmuştur. Sinzig, Walter, ve Doepfner (2009) çalışmasında otizm spektrum bozukluğu tanısı alan vakaların \%70 oranına yakın DEHB semptomlarına sahip olduğu bulgusuna ulaşmıștır. Öyle ki bu sürecin sonunda Ruhsal Bozuklukların Tanısal ve Sayımsal El Kitabı'nın son basımında (DSM-IV) her iki bozukluğun tanı kategorisi ile ilgili değişikliğe gidilmiş, norogelişimsel bozukluklar başlı̆̆1 altına taşınmıştır. Bu çalışma kapsamında DSM-IV'teki güncel değişiklikleri temel alarak, her iki bozukluk genetik, bilişsel, nörolojik, davranışsal, sosyal ve duygusal bakımdan benzer ve farklı yönleriyle ele alınmıştır, güncel durumun avantaj ve dezavantajları tartışılması amaçlanmıştır. Son olarak da güncel tedavi yaklaşımları ve bu yaklaşımların etkililiğine ilişkin çeşitli çalışmalar, derleme makalesine özgü 
değerlendirmeleri içeren yöntemle sunulmuştur. Alanyazındaki farklı çalışmaların derlenmesiyle varılan noktada nitel çalışmalar için de değerli bir alt yapı oluşturacağı düşünülmektedir.

\section{Toplumda Görülme Sıklı̆̆ı (Prevalansı)}

Dikkat eksikliği hiperaktivite bozukluğu (DEHB) ve otizm spektrum bozukluğu (OSB) nörogelişimsel aksaklıklarla bilinen, erken yaşlarda tanı alıp yaşam boyu süregiden bozukluklardır. Dikkat eksikliği hiperaktivite bozukluğunda ve otizm spektrum bozukluğunun toplumda görülme sıklı̆̆ına ilişkin sonuçlara göre; DEHB çocukluk çağının en çok tanı konulan nöropsikiyatrik hastalıklarından olup okul çağındaki çocuklarda yaygınlığı dünya çapında toplam nufusun \%7,2'si (129 milyon) ve yetişkinlerde \%4.4 kadardır (Polanczyk vd., 2014; WHO, 2019; CHADD, 2020). Ülkemizde çocuklarla yapılan bir çalısma sonucunda, DEHB yaygınlık oranı \%13.8 olarak belirlenmiştir (Ercan, 2010). Dünya genelinde DEHB'unda erkek/kız oranı yaklaşık 2/1'dir ve ülkemizde yapılan bir çalışmada bu oran 3,23 olarak bulunmuştur (Ercan, 2010). Cinsiyet farklılığındaki bu durumun nedeninin erkek çocuklarda dışa vurumun daha fazla olmasından kaynaklandığı öne sürülmüştür. Otizmin yaygınlık oranları her ülkede farklı rapor edilmektedir. Ülkelerin prevalans çalışmaları incelendiğinde OSB yaygınlık oranları \% 0.07 ile \% 2.6 arasında değiştiği görülmektedir (Christensen ve ark., 2018; Fombonne, 2009; Kim ve ark., 2011). Türkiye'de yapılan bir çalışmada, 18-30 aylık çocuklarda OSB prevalansı 1/1000 olarak bildirilmiştir (Kondolot ve ark, 2016). Otizmde Hastalıkları Kontrol Etme ve Önleme Merkezi (Centers for Disease Control Prevention)'nin verilerine göre 2006 yllında her 150 çocuktan 1'inde otizm görülürken, 2018 yllında verilen son bilgiye göre de, her 59 çocuktan 1'inde otizm görülmektedir. Son yillarda yapılan araştırmalar Otizm Spektrum Bozukluğu tanısında giderek artışın nedeni büyük oranda açıklanamamakla birlikte tanısal değişiklikleri $\% 27$, sosyal etkilerin $\% 16$, anne baba yaşındaki artışın \%11 ve coğrafi etmenlerin \%2 oranında rolü olduğu tespit edilmiştir (Öztürk, 2015). Bu bölümün yazılması kapsamında yapılan alanyazın incelenmesinde, DEHB tanısı olan bireylerde OSB prevalansı ile ilgili meta-analiz çalışması bulunamamıştır. DSM'nin önceki sürümünde (DSM-IVTR, 2000) E Kriterinde, dikkatsizlik ve/veya hiperaktivite/dürtüsellik belirtilerinin, OSB'nun daha temel (az yoğun) bir ifadesi olduğu görüşü, OSB’nin tanısal hiyerarşi içinde en yoğun uçta kabul edilmesine, bu nedenle ADHD tanısı olan kişinin OSB eş tanısı almamasına neden olmuştur. OSB temel klinik tanısı olan bireylerde DEHB belirtilerinin görülme sıklı̆ıının genel popülasyonda ve toplum temelli çalışmalarda \% 13 ila 50 ve klinik örneklerde \% 20 ila 85 arasında olduğu bildirilmiştir (Grzadzinski vd., 2011). 


\section{Eş tanı ve ayırt edici tanı}

Dikkat eksikliği hiperaktivite bozukluğu ve otizm spektrum bozukluğu DSM IV'te yaygin gelişimsel bozukluklar başlığı adı altında birlikte anılan bozuklukların başında gelmektedir (Amerikan Psikiyatri Birliği, 1994). DSM-IV'te yapılan değişiklikle birlikte eş tanı alabilir duruma gelmesiyle benzer ve farklı özellikleriyle incelenmesi tanı ve tedavi açısından kritik bir öneme sahip hale gelmiştir. Klinikte OSB ve DEHB tanınması ile temel sorun tartışmalı olarak ayırıcı tanı ile ilgilidir (Cortese, 2016). Otizm Spektrum Bozukluğuna eşlik eden psikiyatrik bozuklukları tanılamayı zorlaştıran faktörlerin başında OSB olan kişilerin kendi duygu, hislerini ve ruhsal durumlarını işlemleme ve tarif etmekte yaşadıkları güçlükler gelmektedir. Genellikle diğer psikopatolojilere ait belirtiler OSB`nun tipik belirtileri tarafindan örtüldüğü için fark edilmesi güçleşebilmektedir (Görmez ve Kırkpınar, 2015). Örneğin, OSB tanısı olan kişilerin DEHB tanısı eşlik ettiği durumda rutine, düzene daha az meyilli davranışlar sergilemesi, DEHB'li grupta otizm tanısı olabilecek kesimin gözden kaçmasına yol açabilmektedir. Öteyandan, OSB'ndaki sosyal olarak kendini baskılama yeteneğinin bozulması (dizinhibisyon) DEHB'deki dürtüsellik gibi anlamlandırılırak tanı açısından yanıltıcı olabilmektedir (Özeren, 2013). Bu gibi durumlar her iki bozukuğun da tanınmasina ve tedavisinde dezavantaj haline gelebilmektedir.

DSM IV-TR'nin geçerli olduğu dönemde otizm spektrum bozukluğunda hiperaktivite belirtisinin sıklıkla görülmesi, her iki bozukluğun da fenotipiklik açısından birbiriyle yüksek düzeyde benzerlik göstermesi, otizmde dikkati sağlayan sistemlerde sorun olduğunu ve OSB ile DEHB arasında bir akrabalık olabileceğini düşündürmüştür (Sinzig, Walter ve Doepfner 2009). Bu bulgular OSB ile DEHB'nin bazı belirtilerinin birbirine oldukça yakın olduğunu, hatta iki yetersizliğinin eş tanı alabileceği düşündürmüştür. OSB tanılı çocukların ailelerinden toplanan verilerin analizine göre, DEHB tanısı olan çocukların \%87'sinin OSB tanı bileşenin en az bir kriterlerini karşıladığı (Ames ve White, 2011), OSB olan çocukların DEHB tanı kriterlerinde \% 43 (Kılınçaslan Motavalı, Sözen Küçükyazıc11 ve Gürvit, 2010) ila \%87 (Ames ve White, 2011) arasında tanı eşiğini geçtikleri görülmüştür. Eş tanı olduğu duruma bakıldığında DEHB tanısı olan çocuklarından \% 7 'sinin yüksek düzeyde OSB belirtisi de göstermekte olduğu görülmüştür. Ayrıca bu çocukların \%59' unun da orta düzeyde OSB tanısına uygun benzer davranışlar sergilediği belirtilmiştir (Mulligan ve ark., 2009). Bu durum yaş ilerledikçe de süreğenlik de göstermekte, DEHB'nun erişkin OSB'deki prevalansı \% 42-68 arasında değişmektedir (Joshi, Wozniak, Petty, Martelon, Fried, Bolfek vd., 2013). Otizm spektrum bozukluğu tanılı bazı bireylerin, DEHB için tam kriter karşılayabildiği görülmüştür (Kılınçaslan, Mukaddes, Küçükyazıcı ve Gürvit, 2010). Ayrıca, hafif OSB tanısı olan alt grupta (özellikle, daha önce Asperger sendromu olarak adlandırılan durum), klinik sevk sağlanabilmesi için, 
OSB'nun çekirdek semptomlarından kaynaklanan bozulma yerine DEHB belirtileri kriter alınmaktadır (Cortese vd., 2015). Bu nedenle, DSM-IV-TR DEHB ölçütü E kriteri göz önüne alındığında, OSB tanısı olan bireylerde DEHB benzeri semptomların OSB tanısının semptomları üzerinde etkide bulunması mümkün olduğu görülmektedir (Cortese, vd., 2015; Kllınçaslan, Mukaddes, Küçükyazıcı ve Gürvit, 2010). Bu sorunu kabul ederek, DSM'nin en son sürümü (DSM5), DEHB ve OSB'nun eş tanısına izin verecek şekilde düzenlenmiştir. Her iki bozukluk da DSMIV'de yaygın gelişimsel bozukluk başlığı adı altında yer alırken, DSM-IV'te bu tanı adı tamamen kaldırılmış, tanı grubunun ismi içeriği ve tanı ölçütleri ile ilgili değişiklikler yapılarak, nörogelişimsel bozukluklar adı verilen yeni bir başlıkta yer almasına karar verilmiştir. Ayrıca tanıya eklenen bazı belirleyicilerle başka bir nörogelişimsel, ruhsal ya da davranışsal bozuklukla ve bilinen tıbbi ya da genetik bir durum, ya da çevresel bir etmenle ilişkili olup olmadığının kodlanması beklenmektedir (Amerikan Psikiyatri Birliği, 2013).

Otizmde ve DEHB tanısı konulmasında en yaygın kullanılan tanısal ölçütler, DSM-IV (Amerikan Psikiyatri Birliği), ICD (Uluslararası Hastalık Sınıflandırılması) ve WHO (Dünya Sağlık Örgütü) tarafından kabul edilmiş ölçütler olup uzmanlar tarafindan OSB ve DEHB konusunda yapılan araştırmalarda bu ölçütler kabul görmektedirler. Bu çalışmada DSM-IV'te tanımlandığı şekliyle Otizm spektrum bozukluğu, sosyal ve iletişim becerilerinde yetersizlikler ile sınırlı, tekrarlayıcı ve belli bir amacı olmayan ritmik davranışlar (stereotipik) ve ilgiler; DEHB dikkatsizlik, aşırı hareketlilik ve davranışlarına sınır koymada güçlük (dürtüsellik) belirtileri ile kabul edilmiştir. (Amerikan Psikiyatri Birliği, 2013). Otizm Spektrum Bozukluğunun, Amerikan Psikiyatri Birliği’nin (2013) yeni düzenlemesinde eşlik eden diğer bozukluklar ile birlikte tanılanmasına izin veren değişiklikler gerçekleştirilmiş ve giderek yaygınlaşan bir bozukluk olduğunu belirtilmiştir. DSM-5’te Otizm Spektrum Bozuklukları (OSB), başı başına tek bir tanı kategorisi olarak belirlenmiş ve sorunlar; A) toplumsal iletişim, etkileşimde sorunlar, B) sınırlı, tekrarlayıcı davranış, ilgi alanı ya da etkinlikler olmak üzere iki ana boyutta tanımlanmıştır (Amerikan Psikiyatri Birliği, 2013). Dikkat Eksikliği ve Hiperaktivite Bozukluğu (DEHB) ise DSM IV’te olduğu gibi dikkat eksikliği ve dürtüsellik/aşırı hareketlilik olmak üzere iki boyut, üç alt boyut üzerinde tanımlanmıştır: (1) dikkat eksikliğinin ön planda olduğu tür, (2) dürtüsellik/aşırı hareketliliğin ön planda olduğu tür ve (3) birleşik tür olarak tanımlanmıştır. Ancak tanı kategorisi değiştirilmiş ve yaygın gelişimsel bozukluk yerine nörogelişimsel yetersizlikler başlığı adı altında yer almasına karar verilmiştir.

Otizm Spektrum bozukluğu ve dikkat eşikliği hiperaktivite bozukluğu arasındaki örtüşme oranları iki bozukluk arasında bir akrabalığa işaret ediyor gibi görünse de çevresel faktörlerin etkisi de göz ardı edilemez. Dikkat Eksikliği Hiperaktivite Bozukluğunun etyolojisindeki çevresel etkenlerin 
incelendiği bir derleme çalışmada tüm çevresel faktörlerin genetik faktörler ile birleştiklerinde etki gösterdikleri ancak bu mekanizmaların ayrıntılı anlaşılmasının gerekliliği vurgulanmıştır (Gül ve Öncü, 2018). DEHB ve OSB arasındaki ilişkinin niteliksel olarak incelendiği araştırmalarda iki yetersizlik türü arasında etiyolojik ve klinik düzeyde bazı benzerlikler olduğunu öne süren çalısmalar olduğu gibi bunun aksini iddia eden ve farklılıklara işaret eden çalışmalar da görülmektedir. İlerleyen bölümde bu araştırmalara yer verilirken, her iki bozukluğun sahip olduğu genetik ve çevresel faktörleri ile farklı faktörlerin etkileşimleri sunulmaktadır.

\section{Genetik İncelemeler}

Otizmle ilişkili oldugu düşünülen genler; on besinci kromozom, on üçüncü kromozom, altınc1 kromozom ve yedinci kromozom üzerinde yer almaktadır. Otizm spektrum bozukluğunun genetik temellerinin incelendiği çalışmalara göre otizmin tek yumurta ikizlerinde çift yumurta ikizlerine oranla daha fazla görünmesi, bazı ailelerde birden fazla otistik çocuğun olması ve erkeklerde kızlara göre 3-4 kat daha fazla görülmesi, Otizm tanılı çocukların ailelerinden alınan kan örneklerinde seretonin düzeyinin yüksek olması OSB'nun genetik bir temeli olduğunu düşündürmektedir (Christensen vd., 2018). Ancak otizm tanılı çocukları olan bir ailenin ikinci çocuklarında otizm ve benzeri durumların görülme oranı \% 4-10 arasındadır ve çift yumurta ikizlerinde bile eştanı oranı \%70'e ulaşmaması, otizmin yalnızca genetik etmenlere bağlı olmayıp çevresel nedenlere de bağlı olduğu görüşünü desteklemektedir (Angell, Meadan ve Stoner, 2012).

Dikkat eksikilği hiperaktivite bozukluğu ile ilişkili olduğu düşünülen genler; On altıncı kromozomda yer alan "kaderin" (CDH13) geninde, on yedinci kromozomda yer alan SLC6A4 genindeki varyasyonların etkili olduğu sonucuna ulaşılmıştır (Banaschewski, Becker, Scherag, Franke ve Coghill, 2010; Zhou ve ark. 2008). OSB ve DEHB arasındaki olası örtüşmeler/farklılıklar üzerine alanyazın henüz başlangıç aşamasındadır. İkiz tabanlı yapısal denklem modelini kullanarak yürütülen bir çalışmada, OSB ve DEHB belirtileri arasında $r=0,72$ düzeyinde bir fenotipik ilişki ortaya konulmuştur (Reiersen, Constantino, Grimmer, Martin ve Todd 2008). Genom çapında ilişkilendirme çalışmaları (GWAS), yüzlerce veya muhtemelen binlerce ortak ve nadir genetik varyantın DEHB) ve OSB riskine katkıda bulunduğunu göstermektedir (Lee ve ark., 2013). Her iki hastalık da yüksek oranda kalıtsaldır ve birçok yaygın ve nadir genetik riski paylaşır (Antshel, ZhangJames ve Faraone, 2013; Zafeiriou, Ververi, Dafoulis, Kalyva ve Vargiami, 2013). Bu genetik yapıdan birinin SLC9A9 geni olduğu bilinmektedir. Dikkat eksikliği hiperaktivite bozukluğu, OSB ile ilişkisi olduğu bilinen SLC9A9 genine ait NHE9'un protein fonksiyonlarındaki bozulmanın muhtemelen DEHB ve OSB’unun altında yatan sebep olacağını düşünülmektedir (Zhang-James, Vaudel, Mjaavatten, Berven, Haavik, ve Faraone, 2019). Glutamatergic and GABAergic gen setleri 
de hem OSB hem de DEHB'unda incelenmektedir (Naaijen vd., 2017). Dikkat eksikliği hiperaktivite bozukluğu (DEHB), OSB tanısına sahip olan bireylerin genetik açıdan da karşılaştırıldığı çalışmalarda 16p13 kromozomu üzerindeki genlerin DEHB ve OSB'unda benzer özelliklere sahip olduklarını bulunmuştur (Smalley ve ark., 2002). Ancak gelinen noktada tek gen veya tek değişken varyasyon birlikteliğinin hiçbiri kendi başına anlamlı olmadığı düşünülmektedir. Aday gen setlerindeki çoklu genetik varyantları bir arada analiz ederek, DEHB ve OSB inhibe edici nörotransmitter sistemlerinin dâhil edilmesini destekleyen genetik ilişkileri anlamanın mümkün olacağı düşünülmektedir (Naaijen vd., 2017).

Otizme benzer şekilde DEHB tanısının da erkeklerde kızlardan 2-4 kat daha fazla konması genetik bir temeli olduğunu düşündürürken (Çetin ve Iş1k, 2018); kızlarda daha geç yaşlarda tanı konması daha geç fark edilmesinden kaynaklanmakta, çocukluk dönemi sonrasında cinsiyetler arasındaki farkın azaldığı gözlenmektedir (Davies, 2014). Asherson (2004) aile çalışmalarında ebeveynlerdeki hastalığın çocuklarda riski yaklaşık sekiz kat artırdığı, kardeş çalışmalarında DEHB olguların kardeşlerinde sağlıklı örnekleme kıyasla riskin yaklaşık üç kat arttığı, ikiz çalışmalarında tek yumurta ikizlerinde çift yumurta ikizlerinden daha fazla olduğu gösterilmiştir (Akt. Çetin ve Işık, 2018). Dikkat eksikliği hiperaktivite bozukluğunun kalıtsal geçişi \%70-80 gibi yüksek bir oranda olmasına karşın (Faraone, 2006), genetik etmenlerin yanında çevresel risk etkenlerinin, bozukluğun açıklanmasındaki gen-çevresel etkileşimleri üzerinden \%10-40 oranında etkilediği düşünülmektedir (Sciberras, Mulraney, Silva ve Coghill, 2017). Son y1llara gelindiğinde gerek OSB gerek DEHB'nin yalnızca genetik özelliklerde açıklanamayacağı anlaşılmış, erken gelişim evrelerinde, çevresel ve genetik faktörlerin etkileşimiyle, nörogelişimsel bir duraksama sonucu ortaya çıkan, nörobiyolojik kökenlere dayanan bir yetersizlik olarak incelenmesi gerektiği öne sürülmüştür (Sonuga-Barke ve Halperin, 2010).

\section{Nörolojik ve Bilişsel İncemeler}

Nörogörüntüleme ve genetik çalışmalardan elde edilen kanıtların artmasıyla, iki hastalık arasında hem örtüşmeye hem de ayırıcı özelliklere işaret eden bulgulara ulaşılmıştır. Yapısal beyin görüntüleme çalışmaları, hem anatomik manyetik rezonans görüntüleme (aMRG) hem de difüzyon tensör görüntüleme (DTG), toplam beyin hacminin OSB'de artmış ve DEHB'de azalmış, amigdala hacminin OSB'de daha büyük, DEHB'unda normal olduğunu işaret etmektedir (Dougherty, Evans, Myers, Moore ve Michael, 2016). Beyin görüntüleme çalışmaları DEHB tanısı olan çocuklarda özellikle de prefrontal korteksin boyut ve etkinliğinin yanı sıra, frontal korteks, serebellum ve subkortikal yapılarda hacim azalması olduğunu göstermektedir (Tuğlu ve Şahin, 2010). Frontal korteksteki anormalliklerin hem DEHB hem de OSB'de gözlemlendiğini belirten araştırmalarda, 
DEHB tanısı alan bireylerde beynin dikkat, yürütücü işlevler ve inhibitör kontrolü düzenleyen bölgeleri olan dorsolateral prefrontal korteks, anterior singulat korteks ile subkortikal yapilar arasındaki nöronal ağlarda da işlevsel bozukluklar tespit edilmiştir (Hart, Radua, Nakao, MataixCols ve Rubia, 2013).

DEHB tanılı çocukların beyni nöroanatomik olarak incelendiğinde, çalışma belleği (bilgiyi mantıklı basamaklarda ele alma yeteneği), soyut düşünce, dürtüselliği ve yürütücü kontrolü (gerçek dünya da başarıyı sağlayan organizasyon, odaklanma, bütünleştirme yeteneği) düzenleyen frontal lob işleviyle ilişkili sorunlar temelde görünmektedir (Bulut, 2016). Brunelle ve arkadaşlarının (2012) otizme ilişkin çalışmasında da belirttiği gibi “sosyal beyin” denilen süperior temporal korteks, parietal korteks ve amigdala gibi bazı beyin bölgelerinde büyümeler, anatomik ve fonksiyonel anormaliler otizmdeki sosyal davranışlardaki anormalliklerle ilişkilidir. Alanyazındaki gelişmelere göre, OSB’li çocuklardaki anormal beyin büyümesi daha yoğun olarak gri maddede değil, beyaz maddede görülmüştür. Frontal, temporal ve parietal lobların gri ve beyaz maddelerinde büyüme rapor edilmiş olsa bile, en belirgin artış frontal loblar için rapor edilmiştir (Erdoğan, Kelten, Akdemir, Karaoğlan ve Taşdemiroğlu, 2013). Ayrıca otizmli çocukların kanında ve vücut sıvılarında nörokimyasal bozukluklar da saptanmıştır (Özeren, 2013). Ancak bu durumun çevresel değişkenlere birlikte incelendiğinde anlamlı olduğu düşünülmektedir. Elektrofizyolojik incelemelerde OSB tanısı olan çocukların kanında anormalliklerinin belirlenmesi sonucunda otizm ile epilepsi arasında bağ olduğu görülmüştür (Parisi, Moavero, Verrotti ve Curatolo, 2010). Otizm spektrum bozuklarında bağışıklık sistemi bozukluklarına da yol açan virüsler, kanın biyolojik yapısındaki farklılıklar, kan akım hızındaki farklılaşmaları, kullanılan ilaçların ve radyasyonun da OSB’unda çevresel faktörler arasında yer aldığı düşünülmektedir (Özeren, 2013). DEHB'unun epilepsi eş tanısında da benzer şekilde çok sayıda faktörün rol oynadığı tahmin edilmektedir (Ekinci ve Toros, 2013). Bu faktörler bazıları beyin işlev bozuklukları, antiepileptik ilaçların olası etkileri, dikkat, uyanıklık, bellek ve işlem hızında bozulmaların bulunduğu bilişsel etkiler olup hem epilepside hem DEHB'de ortak olduğu bilinmektedir (Parisi, Moavero, Verrotti ve Curatolo, 2010; Torres, Whitney ve Gonzalez-Heydrich, 2008).

Alan yazında DEHB'li çocuklarda dikkat esnekliğinden ziyade araştırmanın odak noktası olan dürtüsellik ve anormal ödül işlemlerini kontrol etmedeki çok büyük olumsuzluklara odaklanılmışır (Gargaro, May, Tonge, Sheppard, Bradshaw ve Rinehart, 2018). Otizm spektum bozukluk tanıs1 olan bireylerin dikkat esnekliği ile ilgili zorluk bildirmediğini gösteren çalışmalar olmuştur (Poljac ve ark. 2010). Yapılan sınırlı araştırmaya dayanarak, genel olarak bilişsel esnekliğin DEHB olan bireylerde korunduğu düşünülmektedir (Corbett, Constantine, Hendren, Rocke ve Ozonoff, 2009). 
Bu çalışma kapsamında yapılan incelemede, otistik, DEHB ve otizm-DEHB olan çocuklarda dikkatle esnekliği sistematik olarak inceleyen tek bir çalışma tespit edilmiştir. Bu kapsamda Sinzig, Bruning, Morsch ve Lehmkuhl (2009) çalışmasında elde edilen sonuçlar, grupların dikkat esnekliği ölçütlerinde anlamlı farklılık göstermediğini, ancak otizmli ve ilave DEHB belirtileri olan çocukların en fazla hata gösterdiğini öne sürmektedir. Bilişsel esneklik ve dikkati yönlendirebilme becerisinin değerlendirildiği bir çalışmada; OSB, DEHB, otistik DEHB tanıları olan üç grup ele alınmıştır. Bu çalışmanın sonuçları, dikkat zorlukları olan katılımcıların (Otizm + DEHB ve DEHB), otizm tanısı olanlara göre dikkati sürdürme ve dikkatin yönünü değiştirebilme becerisinde güçlük çektiklerini ortaya koymuştur (Gargaro vd., 2018). Bu bulgulardan hareketle DEHB ve OSB tanısı alan bireylerde, çevresel faktörlerin etkileri en iyi şekilde genetik ve nörolojik süreçleri bilerek davranışsal süreçleri gözlemlenmesiyle anlaşılabileceği düşünülmektedir. Bundan sonraki aşamada genetik, nörolojik ve bilişsel süreçlerin davranışsal yansımaları üzerinde durulacaktır.

\section{Klinik Görünümde Davranışsal İncelemeler}

Dikkat eksikliği hiperkativite bozukluğunda görece iyi olmasına karşın, özellikle otizm spektrum bozukluğunda genetik, nörolojik ve bilişsel süreçlerin en belirgin davranışsal yansımasını sosyal ortamlarda iletişim becerilerindeki yetersizlikler oluşturmaktadır. Otizm spektrum bozukluğu tanısı olan çocukların dikkat eksikliği, dürtüsellik ve hiperaktif davranış örüntüleri sergiledikleri, benzer şekilde DEHB olan bireylerin de sosyal etkileşimde ve iletişimde yetersizlikler gösterebildikleri bilinmektedir (Özeren, 2013). Otizm spektrum bozukluğunda müdahale edilerek kontrol altına alındığ1 durumda iletişim becerileri zamanla gelişme göstermekte yetişkinlikte daha iyi duruma gelmektedir. Otizm konusunda yürütülen çalışmalar sözel iletişim becerisinde zamanla gelişme olduğunu tutarlı bir şekilde bildirilmesine karşın, sözel olmayan iletişimde ise gelişme olmadığını bildirilmektedir (McGovern ve Sigman, 2005; Shattuck, Seltzer vd., 2007). Dikkat eksikliği hiperkativite bozukluğunda akranlarıyla ilişki kurmada ve sosyal ipuçlanını okumakta yaşadıkları güçlüklere bağlı olarak sosyal becerilerde sergiledikleri yetersizlikleri, bireylerin bilişsel ve akademik alandaki sorunları üzerinde önemli etkilerinin olduğu söylenebilir (Ames ve White, 2011). Yapılan bir çalışmada dikkat eksiliği ve hiperaktivite bozukluğundaki anormalliklerin OSB’na özgü sosyal biliş ve dil edinimi süreçlerindeki bozulmalara işaret ettiği görülmüştür (Proal, Gonzalez-Olvera, Blancas, Chalita ve Castellanos, 2013).

Beeger, Malle, Nieuwland ve Keysar'nn (2010) çalışmalarında dikkat eksikliği hiperkativite bozukluğunda ve otizm spektrum bozukluğunun önemli davranısssal yansımalarından biri de duygu düzenleme becerilerinde görülmektedir. Bu çalışmada, normal zekâya sahip ergenlerle otizmliler hipotetik hikâyelere verdikleri tepkiler üzerinden karşılaştırılmıştır. Araştırma bulgularına göre 
otizmli bireyler hikâyelerde kahramanların davranışlarını açıklamada diğer gruba göre daha az zihinsel kavramları kullanmalarına karşın, iletişim ve başkasının perspektifinden bakmada sağlıklı grupla benzer sonuçları almışlardır. Sonuçlar otizmli yetişkinlerin gerçek sosyal aktiviteleri içeren etkinlikleri takip etmede ve açıklamada güçlük çektikleri, ancak belli bir sistemle hazırlanmış başkasının bakış açısını almasını gerektiren durumlarda başarılı olabildiklerini göstermektedir. Bu duruma karşıllık duygu düzenleme becerilerinin değerlendirildiği çalışmalarda DEHB’li çocuk ve ergenlerde duygu düzenlemede becerilerinde zorluklar olduğu belirtilmiştir. Buna göre sosyal ilişkilerde amaca uygun davranma, strateji belirleme, dürtüsellik kontrolü, farkındalık ve netlik gibi duygu düzenleme stratejilerinde DEHB tanısı alan bireylerin sağlıklı yaşıtlarına göre daha başarısız olduğu görülmüştür (Anastopoulos, Smith, Garrett, Marrissey-Kane, Schatz, Sommer vd., 2011; Bunford, Evans ve Langberg, 2014). Türkiye'de yapılan bir çalışmada DEHB belirtileri sergileyen çocukların sosyal çerve tarafindan etiketlendiği ve dışlanma ile de sonuçlanabilen kişilerarası sorunlar yaşadıkları öne sürülmüsstür (Şan ve Köse, 2018). Bu bulguların her iki yetersizlik düzeyinde tanı alan kişilerin sosyal ilişkilerinde yaşadı sorunların kaynağına ilişkin örneklere işaret ediyor olabileceği düşünülmektedir.

Dikkat eksikliği hiperkativite bozukluğunda kazara olmasına karşın, özellikle otizm spektrum bozukluğunda kendine zarar verme davranışları bozukluğa ilişkin oldukça belirgin bir davranışsal belirtidir. Otizm spektrum bozukluğunda kendine zarar verici davranışlar, düşük zekâ düzeyi ile ilişkilendirilmektedir. Otizmde görülen acıya aşırı dayanıklılık betaendorfin salgısının yüksek olmasından kaynaklanıp otizmli bir çocuğun, birinci derece yanık olana kadar durabilmesine, saç çekme, dudak ısırma gibi kendine zarar verici davranışlar nedeniyle ciddi zarar görmesine neden olabilmektedir (Özeren, 2013; Sürücü, 2016). Dikkat eksikliği hiperkativite bozukluğunun karakteristik özelliklerinden birisi de ciddi yaralanmalara maruz kalmasına neden olabilen kazaya yatkınlık durumudur (Amerikan Psikiyatri Birliği, 2013). Davranışlarını kontrol etmekte yaşadıkları güçlük nedeniyle, bu çocuklar kazayla yaralama ve dürtüsel davranışlar sonucunda suça sürüklenebilmektedir. Yapılan incelemler DEHB ve davranım bozukluğu tanısının suça sürüklenen çocuklarda en sık görülen psikiyatrik tanılar arasında yer aldığını göstermektedir (Eyuboglu ve Eyuboglu, 2018). Bu çocukların, motor becerilerin zayıf olması da travmaya maruz kalmaları ihtimallerini yaşıtlarına kıyasla arttırmaktadır. Ülkemizde üniversite hastanesinde yapılan araştırmada DEHB tanısı alan çocukların almayan çocuklara göre acil servise ev kazası nedeniyle başvurma oranları anlamlı derecede fazla olduğu görülmüştür (Ceylan ve Kırgızoğlu, 2017; Sarohan, 2017). 
Dikkat eksikliği hiperkativite bozukluğu ve OSB’unda bir diğer önemli davranışsal yansıma saldırganlıktır. Otizmde vurma ve saç çekme ağırlıklı ağırlıklı olmak üzere saldırganlık bazı bireylerde belirgin bir davranış olarak ön plana çıkabilir. Bu davranışlarının çoğunun çocuğu rahatsız eden bir nedenden kaynaklanıyor olup çocuğun tanıdığı ve güvendiği biri tarafindan çocuk sakinleştirilebilmektedir. Şiddet davranışı yabancılara değil genellikle ve sıklıkla aileye, çok yakınlarına, özellikle de kardeşlerine karşı sergilenmektedir (Öztürk, 2015). DEHB tanısı alan çocuklarda ise saldırgan davranışların (özellikle karşıt olma karşı gelme bozukluğu ve davranım bozukluğu eş tanısının varsa) daha fazla görüldüğü saptanmıştır. Aynı çalışmada DEHB tanısı alan çocukların anne-babalarında da bu eğilimin olduğu tespit edilmiştir (Agha, Zammit, Thapar, ve Langley, 2013). Bu sonuç DEHB tanısı alan çocukların saldırganlık davranışını maruz kalma yoluyla ebeveynlerinden öğrendiğini düşündürmektedir. Buna ilişkin ülkemizde yapılan bir çalışmada da DEHB grubundaki çocukların annelerinin saldırganca ve düşmanca tutumlara sahip olma düzeyleri çocuğu tanı almayan gruptaki annelere göre daha yüksek bulunmuştur (Kara, Durukan, Koparan, Altun, Kahraman ve Özkan, 2016).

Dikkat eksikliği hiperkativite bozukluğu ve OSB’unda yeme örnütüleri de farklilık gösterebilmektedir. Otizmlilerde yeme sorunları katı yiyecekleri yemeyi reddetme, çiğnemeyle ilişsili sorunlar, yemek davranışının seçici olması veya nadiren çok yeme isteği, yenilemez maddelerin yeme isteğine sık rastlanabilmektedir (Korkmaz, 2001). Otizmli çocuklarda Gastrointestinal sistem (GİS) yakınmaları yönünden yapılan bir çalışmada bu şikâyetlerin biyolojik nedenlerdense öğrenme, rol alma gibi davranışsal nedenlere bağlı olduğu bildirilmiştir (Ibrahim, Voigt, Katusic, Weaver ve Barbaresi, 2009). Ancak bunun aksine biyolojik temeli olduğunu öne süren hipotezlere göre, beynin ödül merkezindeki dopaminerjik yetersizlik ile glukoz açlığına yatkınlık arasında bir ilişki olduğu savunulmaktadır (Solanto, 2002). Bir bakıma, yemek yendiğinde beyin ödül merkezi sanki bir ödül almış gibi yapay olarak dopaminerjik artış sağlayarak bir çeşit haz vermektedir (Solanto, 2002). Bu da çocuklardaki OSB ve DEHB tanısı olan çocuklarda yeme davranışını tetiklemektedir. Yapılan incelemelerde bu bulguyu destekler şekilde obezite tedavisi gören çocukların büyük bir kısmında (\%58) DEHB saptanmıs, çocukların vücut kitle indekslerinin kontrol grubuna göre daha yüksek olduğu gösterilmiştir (Agranat vd.., 2005).

\section{Sosyal ve Duygusal İncelemeler}

Otizmli çocukların duyu organlarından gelen uyarılara karşı aşırı tepki gösterdikleri ya da hiç tepkisiz kalabildikleri duyusal sorunlarının önemli işaretlerindendir (Korkmaz, 2001). Otizm spektrum bozukluğunda duyusal tepkiler durum ve bağlama göre aşırı yüksek ya da düşük bulunabilir. Örneğin OSB tanılı bir çocuk hafif bir iğne batmasından yoğun acı duyabilir ya da aksine parlak bir 
1şığa çok uzun süre bakabilir (Özeren, 2013). Duyusal sorunların yetişkinlikte de devam ettiğine dair bulgular elde edilse de kişilerin zamanla sorunları daha iyi yönetebildiklerini gözden kaçırmamak gerekmektedir (Crane, Godard ve Pring, 2009). Dikkat eksikliği hiperaktivite bozukluğunun tedavi edilmediği durumda çocukluktan erişkinliğe olan gelişimsel seyrinde aksaklıklar değişerek devam etmektedir. Mannuzza ve Klein (2000) çalışmasında DEHB tanısı olan kişilerin erişkinlik dönemlerinde kontrol grubundakilere kıyasla akademik olarak az başarı gösterdikleri, yakın arkadaşlarının az olduğu, psikolojik uyumlarının ve iş başarılarının düşük, öz güvenlerinin ve sosyal becerilerinin görece az olduğu görülmektedir. Kişilerarası ilişkilerde bozuklukların sözel olmayan iletişim becelerilerindeki bozukluk ile ilgili olabileceği düşünülmektedir (Tatar, Yargıç, Oflaz ve Büyükgök, 2015).

Otizm ve DEHB tanısı alan çocukların duygusal ifadeleri tanıma konusunda farklılıklar sergiledikleri görülmektedir. Örneğin, otizmli çocuklar uygunsuz korkular öne çıkan sorunlar arasındadır. Herhangi küçük bir değişiklik bile onlarda korkuya ve öfke nöbetlerine yol açabilir (Sürücü, 2016). Bunun sonucunda da öfke patlamaları, ellerini başının arasına alarak bağırma, başını sert cisimlere vurarak zarar verme gibi davranışlar gözlenebilir (Öztürk, 2015). DEHB’unda beynin duygulardan sorumlu bölgesi olan amigdalanın faaliyetinde sağlıklı popülasyona göre farklılıklar bulunmaktadır. DEHB olan çocuk ve erişkinlerin, tehdit ilişkili korku ve sinirli ifadelerinin tanınmakta zorlandıkları ve sık sık hatalar yaptıları görülmüştür (Pelc, Kornreich, Foisy ve Dan, 2006; Williams vd., 2008). Yapılan bir çalışmada DEHB tanısı alan bireylerde üzgün, sinirli, iğrenmiş, korkulu gibi bazı olumsuz yüz ifadelerinin, olumlu (mutlu) yüz ifadelerine göre daha fazla hatalı tanımlandığı gösterilmiştir (Rapport, Friedman, Tzelepis ve Van Voorhis, 2002). Ulusal bir araştırmada DEHB grubunda DEHB'undaki dürtüsellik arttıkça, toplam duygunun doğru tanınma oranının azaldığı, sinirli ve korkmuş duyguların yanlış tanınma oranının da arttığı gösterilmiştir (Tatar, Yargıç, Oflaz, ve Büyükgök, 2015). Ay ve Kılıç (2019) tarafından ergenlerle yaptıkları çalışmasında ise salt DEHB olmanın empati düzeylerini etkilemediği, karşı gelme karşıt olma bozukluğu eş tanısı durumunda temel ve duygusal empati düzeylerini azalttığı belirtilmiştir.

Dikkat eksikliği hiperaktivite bozukluğu belirtilerin şiddeti ve görülme sıklığı okul öncesi dönemden her yaşta bireysel farkl1l1klar göstermektedir (Daley, Jones, Hutchings ve Thompson, 2009). Ayrıca bu belirtiler zaman içinde değişime uğrasa da \%50’ye varan oranlarda erişkinlik döneminde de devam ettiği bilinmektedir (Geissler ve Lesch 2011). DEHB belirtilerinin etiketlenme ve dışlanmaya da neden olabilen kişilerarası sorunlara yol açtığı düşünülmektedir (Karabekiroğlu ve arkadaşları, 2009). Yaşıtlar tarafından dışlanma, popüler olamama, diğer çocuklar ve erişkinlerle çatışmaya girme 
ve daha az arkadaşa sahip olmak bu sonuçlardan yalnızca en sık rastlananlarıdır (Şan, Köse, Özbaran, Bildik, ve Aydin, 2018).

Dikkat eksikliği hiperkativite bozukluğu ve OSB'unda fiziksel temas ve yatıştırılabilmeye bağlı bulgular farklılaşmaktadır. Otizmli çocukların bazıları fiziksel temasa yani dokunulmaya asla tahammül edemezken, bazıları bundan hoşlanabilir (Öztürk, 2015). Böyle durum karşısında, OSB tanılı bireylerde uygun bir yaklaşım sağlanabilmesi, kişinin yatışması ve sakinliğini yeniden kazanması için otizmli bireyi uzun süre takip etmek veya yakından tanıyan birinden destek almak gerekmektedir (Sürücü, 2016). Dikkat eksikliği hiperaktivite bozukluğunda genel bir huzursuzluk ve gerginlik hali, kolay ağlama, zor sakinleşme, aşırı hareketlilik bebeklik döneminde sıklıkla gözlenen belirtilerdir. Bu nedenle DEHB tanısı alan çocuklarda kucakta fazla duramama, yakın fiziksel temastan rahatsız olma, diş uyaranlara (ses, dokunma) aşırı tepki verme, göz temasının olmaması ve uyku sorunlarına (az uyuma, sık s1k uyanma gibi) sıklıkla rastlanır (Kırnaz, 2017).

Uzun yıllar sanılanın aksine OSB'nda, çocuğun otizme bağlı belirler sergilemesinin duygusal gereksinimlerini karşılayamayan 'soğuk anne' tutumuna karşı bir tepki olduğu görüşü alanyazında yapılan çalışmalarla desteklenmemiştir (Yüksek, 2015). Ülkemizde yapılan annenin gebelik stres düzeyinin OSB ve DEHB üzerindeki etkisinin incelendiği bir çalışmada DEHB ve karşıt olma karşı gelme bozukluğu (KOKGB) olan gruba kıyasla Otizm üzerinde daha fazla etkili olduğu bulunmuştur. Aynı çalışmada anne sütü kullanım süresinin de OSB tanısı alan çocuklarda daha kısa olduğu bildirilmiştir (Say, Bekiroğlu, Kabadayı ve Yüce, 2015). Ebeveynliğin DEHB gelişiminde temel bir neden olmaktan çok, hazırlayıcı ve bozukluğun ortaya çıkışını hızlandırdığı bilinmektedir. Buna göre ebeveynin sahip olduğu eğitim düzeyi, kalabalık aile ya da tek ebeveynli aileler, annenin doğum yaşının küçük oluşu doğum sonrası depresyonu ve sosyoekonomik düzeyin düşük olması gibi etkenler DEHB için de risk oluşturan psikososyal etkenler olarak belirtilmektedir (Kültür ve Ötekin, 2017; Rice ve Thaper, 2010). Bu nedenle her iki bozukluğunda doğum öncesinden başlayarak doğum sonrası süreçte ve yaşam boyu incelenmesinin uygun olacağı düşünülmektedir.

\section{Gelişimsel ve Sosyal İncelemeler}

Otizmin genetik geçişine vurgu yapan doğum öncesi döneme ait bir çalışmada OSB’unda anne ile fetüs arasında bağışıklık sistemi uygunsuzluğun rolü olduğunu benimseyen görüş otizm tanısı almış olguların bir kısmında bebeğin lenfositlerinin (bağışıklı̆̆ın düzenleyici ve koruyucu) anne antikorlarına tepki verdiğini belirlenmiştir (Vargas, Nascimbene, Krishnan, Zimmerman ve Pardo, 2015). Bu bulgunun doğum sırasındaki ve sonrasındaki hasarın otizmle ilişkisini desteklediğini düşündürmektedir (Özeren, 2013). Buna karşın DEHB olan çocuklarda ülkemizde yürütülen bir 
çalışmada ise yeni doğan çocukların, tanıla ilişkili olduğu nötrofil/lenfosit (NLO) ve trombosit/lenfosit oranları (TLO) arasında sağlıklı yaşıtlarına kıyasla anlamlı bir fark bulunamamıştır (Binici ve Kutlu, 2019).

Dikkat eksikliği ve hiperaktivite bozukluğunun doğum öncesi sürecinin incelendiği baz1 araştırmalarda annenin hamilelik sırasındaki sigara, alkol ya da madde kullanmasıyla bebeğin dikkat eksikliği, hareketlilik, dürtüsellik ve istenmeyen davranış kontrolündeki sorunlarla arasında doğrudan ilişki olduğu gösterilirken (Ellis, Berg-Nielsen, Lydersen ve Wichstrømi 2012, Kovess ve ark. 2015, Palmer vd., 2016); zayıf bir ilişki olduğunu veya hiç ilişki olmadığı gösteren araştırmalar da bulunmaktadır (Yolton, Cornelius, Ornoy, McGough, Makris ve Schantz, 2014, Gustavson vd., 2017). Benzer şekilde OSB'unda da alkol, madde ya da sigara kullanımına ilişkin bulgular tutarsızlık göstermekte, ayrıca bu konuda oldukça az sayıda çalışma bulunmaktadır (Özeren, 2013). Doğum öncesi annenin kilosunun araştırıldığı bir çalışmada ise gebelik öncesi annenin obezite seviyesindeki artış, çocuklarda DEHB için bir risk faktörüyken; annenin obezitesi olması ya da vücut kitle indeksinin altında bir kiloya sahip olması da OSB için risk faktörü olduğu bulunmuştur (Andersen, Thomsen, Nohr, ve Lemcke, 2018).

Doğum sonrası süreçte hastalıkların seyrine bakıldığında DEHB ve OSB her ikisi de erken başlangıçlı nörogelişimsel yetersizlikler olduğu görülmektedir. Otizm spektrum bozukluğunda (OSB) belirtiler 12-24 aylar arasında başlar, şiddetli durumlarda 12 aydan önce veya hafif olgularda 24 aydan sonra fark edilebilir. Aileler tarafından sıklıkla rapor edilen, daha önce kazanılan yetilerin yitimi (regresif otizm) de yine bu aylar arasında gerçekleşmektedir (Amerikan Psikiyatri Birliği, 2013; Öztürk, 2015). Otizm Spektrum Bozukluğunda 15.- 30. aylar arasında gelişimsel gerileme başlayabileceği ve önceden edinilmiş fiziksel ya da sosyal tepki verme becerisinde azalma ile ifade edilmektedir (Öztürk, 2015). Dikkat eksikliği hiperaktivite bozukluğu'nda okul öncesinde tanı alması ve farklı ortamlarda bozukluğu temel belirtilerinin doğrulanması ve normal gelişimsel özelliklerden bağımsız olması gerekmektedir. Özellikle dört yaşından önce gözlenen aşırı motor etkinliğin normal gelişimsel özelliklerden ayırılması zor olmaktadır (Öztürk, 2015).

Hem OSB hem de DEHB tanısıyla çalışırken sosyal gelişimin en temel göstergelerinden biri olan dil problemleriyle ilgili belirtilerin olabileceği bildirilmiştir (Geurts ve Embrechts 2008; Leonard, Milich ve Lorch, 2011). Otizm tanılı çocuklar genellikle konuşulan dilin gelişimini gecikir, normal ileri-geri konuşmalarda başarısız olur ve dili basmakalıp ve tekrarlı bir şekilde kullanırlar (Amerikan Psikiyatri Birliği, 2013). Gillespie-Lynch ve arkadaşlarının (2012) yaptıkları bir çalışmada OSB’unda erken çocukluk döneminde "ortak ilgiye tepki verme” ve dil becerisinin yetişkin dönemi için önemli 
bir gösterge olduğunu ortaya koymuşlardır. DEHB için tanısal kriterler aynı zamanda aşırı konuşma, başkalarına müdahale etme ve söylenenleri dinlememe gibi sosyal iletişim işlev bozukluğunu öneren davranışları da içermektedir (Amerikan Psikiyatri Birliği, 2013). Bu iletişim eksiklikleri, OSB ve DEHB olan kişiler için tipik olan sosyal etkileşim sorunlarına katkıda bulunabilir.

Otizm spektrum bozukluğu olan çocuklarda bazı çalışmalarda dil gelişiminde epilepsi başlangıcı ile dil gelişiminde ve dil edinim becerilerindeki gerileme arasında ilişki olduğu gösterilmiştir (Davidovitch, Glick, Holtzman, Tirosh ve Safir, 2000; Shinnar vd., 2001). Otizmde epilepsinin ortaya çıktığı iki ana dönem erken çocukluk ve ergenlik dönemleridir, ancak bu konudaki bilgiler hala tartışmalıdır (Tuchman, Cuccaro ve Alessandri, 2010). Dikkat eksikliği-hiperaktivite bozukluğu da çocukluk çağı epilepsisi ile ilişkilendirilmiştir. Genel popülasyonda, DEHB prevalansı yaklaşık \% 5 iken, epilepsi tanısı olan çocukların çoğunluğu DEHB eştanısı da aldıkları görülmektedir. Prevalans rakamları, çalışılan numuneye ve tanı için kullanılan kriterlere bağlı olarak \% 8 ila 77 arasında değişmektedir (Dunn, Austin, Harezlak ve Ambrosius, 2003). Ancak DEHB tansına eşlik eden epilepsi herhangi bir gerileme durumu ile ilişkilendirilmemiştir.

Gelişimsel sürecin önemli bir basamağı olan snaptik budamanın en yoğun olduğu ergenlik dönemi DEHB ve OSM tanısı olan çocuklarda daha farklı yaşanmakatadır. Otizm spektrum bozukluğu tanısı almış çocuk/ergenlerde cinsel gelişim sürecinde de sorunlar yaşanabildiği, bu tanıyı alan ergenlerde en kritik konunun sosyal ve cinsel ilişkiler alanında uygun davranışın nasıl öğretileceğidir (Özeren, 2013; Öztürk, 2013). Otizm Spektrum bozukluğu olan çocuklar yaşıtlarından farklı olarak içgüdüsel ve rastgele davranışlar sergileyebilmektedir. Barkley, Fischer, Smallish, Fletcher (2006) DEHB tanısı alan bireylerin yaşıtlarına kıyasla ilk cinsel ilişki deneyimlerinin daha erken yaşta olduğunu, daha fazla seks partnerine sahip oldukları ve istenmeyen gebelikle karşılaşma durumunun daha fazla olduğunu bulgulamıştır. Sarver, McCart, Sheidow ve Letourneau (2014), uyuşturucu kullanımından yargılanan 115 ergenden (12-17 yaş, \% 84 erkek) oluşan bir örneklem ile yaptı̆̆1 çalışmanın sonucunda, DEHB'nun eş tanı olarak yıkıcı davranım bozukluğu tanısı ile birlikte olduğu durumda riskli cinsel davranışta bulunma olasıllı̆̆ının arttığını göstermektedir. DEHB’nin, özellikle iyi tedavi edilmeyen DEHB'nin ergenlikte artmış dürtüsellikle birlikte riskli davranışların yanı sıra istismar riskini artırabileceği bildirilmiştir (Briscoe-Smith ve Hinshaw, 2006).

Özetle, bazı belirtilerde zaman içinde değişiklik görülse de OSB ve DEHB süregiden yetersizlikler olduğu görülmektedir. Otizm spektrum bozukluğu ve ADHD ile çalışırken bir yandan da aile ve de öğretmen ile işbirliği halinde çalışmanın çocuklara, güçlüklerle nasıl baş edecekleri konusunda 
yardımcı olacağı ve kendi kendine yetebilen yetişkiler olarak yetişmelerinde önemli bir rolü olduğu vurgulanmaktadır (Öztürk, 2015).

\section{TEDAVİ YAKLAŞIMLARI}

Dikkat eksikliği ve hiperaktivite bozukluğunda ilaç tedavisinin yanı sıra davranışsal tedaviler de uygulanmaktadır. Psikoterapötik müdahalelere yanıt vermeyen tedavi sürecindeki kişilerde tedavinin etkililiğini arttırmak için ilk olarak tercih edilen yöntemlerin başında ilaç tedavileri gelmektedir (Pliszka vd., 2007). OSB'nun tedavisi tam anlamıyla henüz mümkün değildir. Kullanılan tedavi yöntemleriyle bazı belirtileri hafifleterek, otizmli bireyin kendisi ve ailesinin yaşam kalitesini artırmak hedeflenmektedir (Öztürk, 2015). Otizm hastalarında tanıya yönelik değerlendirme amacıyla kullanılmak üç basamak uygulanmaktadır. Buna göre ilk basamak "klinik genetik değerlendirme", ikinci basamak "genetik tabanlı laboratuar testleri" ve son basamak ise "klinik ve test sonuçlarına dayalı genetik danışma"dır (Gurrieri, 2012).

\section{İlaç Tedavileri}

Dikkat eksikliği hiperaktivite bozukluğunun tedavisinde kullanilan ilaçlar arasında psikostimulan (örneğin, metilfenidat ve amfetaminler) ve psikostimulan olmayan ilaçlar (örneğin atomoksetin veya guanfasin) yer almaktadır. Çocuklar ve/veya yetişkinlerde yapılan çeşitli meta-analizlerde, psikostimulanların (örneğin, metilfenidat) veya karışı amfetamin tuzları ve diğer amfetamin türevlerinin, DEHB berlitilerini kontrol etmek için, en azından kısa vadede plaseboya göre anlamlı derecede daha etkili olduğu aktarılmıștır (Cortese, 2016). Faraone ve Buitelaar (2010) tarafindan yapılan meta analiz çalışmasında psikostimulanların DEHB'nin temel belirtileri üzerindeki etkililik oranı (metilfenidat için 0.72 ve amfetaminler için 0.99), psikiyatride mevcut tüm farmakolojik tedavileri göz önünde bulundurulduğunda en yüksek olanlar arasındadır. Psikostimülanlar, uzun süreli (> 12 ay) çalışmalardan elde edilen sonuçları değerlendirildiğinde de etkili bulunmuştur (Maia ve ark., 2017). Atomoksetin gibi psikostimulan olmayan tedavilerin de kısa vadede DEHB'nin temel semptomları üzerindeki etkinliği bakımından psikostimulanlardan daha küçük etki büyüklüklerine rağmen (ES: 0.6) anlamlı etkisi olduğu görülmüştür (Schwartz ve Correll, 2014).

Otizmin tedavisi için ise farklı seçeneklerden söz edilmektedir. Bunlardan başlıcaları kanıtlara dayalı uygulamalar, yapılandırılmış tedavi modelleri, tamamlayıcı ya da alternatif tıp önerileri (özel beslenme programları, vitamin mineral destekleri, bağırsak mikrobiyotasının incelenmesi vb.) ve psikoterapik ilaçlardır (Mire, Raff, Brewton ve Goin-Kochel, 2015). Otizm spektrum bozukluğunun oluş nedenine ilişkin henüz bir ilaç tedavisi bulunmamakta, ilaç tedavisi belirtilere 
yönelik kullanılmaktadır. Bu ilaçların kullanım amacı ise belirtileri denetim altına alarak çevre ile iletişim ve etkileşimde yaşam kalitesini arttırmaktır (Öztürk, 2015). Otizm için kesin bir beslenme tedavisi yaklaşımından söz edilememekte, her çocuk bireysel olarak değerlendirilmesi önerilmektedir. Aksi halde uzun süreli besin kısıtlamaları sonucunda besin ögesi yetersizlikleri görülmektedir (Girli, Özgönenel, Sarı ve Ardahan, 2016). Otizm tedevisinde özel bir diyet kullanması planlanıyor ise çocuğun besin ögesi yetersizlikleri ve bunların nedenleri, varsa otizme eşlik eden hastalığı, çocuğun besinlere olan yaklaşımı göz önüne alınarak kişiye özel beslenme planı ve stratejisi geliştirilmesi en uygun yöntem olarak önerilmektedir (Girli, Özgönenel, Sar1 ve Ardahan, 2016). Günümüzde otizme yönelik tüm tedavi yaklaşımları otizmin ortadan kaldırılmasından ziyade, otizmli bireylerin bağımsız yaşam becerilerini geliştirmeyi, yaşam kalitesini arttırmayı, sosyal yaşam ve iletişim becerilerini geliştirmeyi amaçlamalıdır.

Psikostimulanların OSB eş tanısı olan çocuklarda DEHB belirtileri için kullanıldığında, OSB eş tanısı olmayan DEHB olan çocuklara göre biraz daha az etkili ve daha az tolere edilebildiğine dair meta-analitik kanıtlar vardır (Reichow, Volkmar ve Bloch, 2013). Özellikle sosyal geri çekilme ve huzursuzluk belirtilerinin oranları, OSB eş tanısı olmayan DEHB'li okul öncesi çocuklarda bildirilenlerden daha yüksektir. Psikostimulan olmayanlara gelince, en son atomoksetin çalışmalarının sistematik olarak gözden geçirilmesi, OSB tanısı olan çocuklarda DEHB belirtileri için klinik uygulama potansiyeline sahip olduğu sonucuna varılmasına rağmen, bu ifadeyi destekleyecek yeterli kontrollü klinik çalışma olmadığı görülmüştür (Ghanizadeh, 2013).

\section{Uygulamalı Müdahaleler}

Her iki bozukluk için de ilaçlar kısa/orta vadede kontrollü çalışmalarda ilk tedavi olarak etkili olsa da (en azından ciddi vakalar için), tek başına yeterli değildir ve bir dizi potansiyel sınırlamalarının her biri bazı hastaları etkilemektedir. Bunların ilaç kullanımını hastaların gözünde sınırlayan etkiler arasında en belirgin olanları (1) tedaviye kısmi cevap alma ya da alamama, (2) olas1 yan etkiler (3) uzun vadeli maliyetler ve faydalarla ilgili belirsizlik (4) zayıf bağlllık ve (5) hastalar, ebeveynler veya klinisyenler tarafından ilaçla ilgili olumsuz tutumlardır (Cortese, 2016). Bu sınırlayan etkilerin profesyoneller tarafindan bilinmesi, etkili müdehale ve en yüksek yararın sağlanması için hem tanı alan kişinin hem de ailenin süreçteki desteğinin ve katılımının sağlanması oldukça önemlidir. En etkili ve verimli yolun ilaca ek olarak uygulamalı müdehaleler olduğu bilinmeli, ilaç kullanımı konusunda gerçek, etkili ve yapıcı önerilere ek olarak uygulanabilecek etkili ve etkili olmayan müdehalelerin aile tarafından bilinmesi sağlanmalıdır. 
$\mathrm{Bu}$ aşamada Otizmde ilaç dışındaki uygulamalarda, müdahalelerin bilimsel dayanağı ve etkililiği konusunda önemli bazı kuruluşların öncü çalışmalarının takip edilmesi önerilmektedir. Bunların başında Amerikan Ulusal Otizm Merkezi (National Autism Center; NAC) (http://www.nationalautismcenter.org), Orelena Hawks Puckett Enstitüsü gibi kâr amac1 gütmeyen organizasyonlar ile Özel Gereksinimli Çocuklar Birliğine bağlı Erken Çocukluk Bölümü, Amerikan Psikoloji Birliği, Amerikan Konuşma, Dil, İşitme Birliği gibi mesleki organizasyonlar da bilimsel dayanaklı uygulamaların belirlenmesine yönelik sistematik alan yazın taramaları ve metaanalizler yapmaktadırlar (Odom, Brantlinger, Gersten, Horner, Thompson ve Harris, 2005; Reichow, 2016). Bir uygulamanın bilimsel dayanaklı olup olmadığını belirlemede dört kriter kullanılmaktadır: (1) çalışmalarda kullanılan araştırma deseni, (2) yapılan çalışmaların yöntemsel kalitesi, (3) aynı bulguları destekleyen yüksek kaliteli çalışma sayısı ve (4) bulguların güçlülüğü ya da etki büyüklügü (Cook ve Cook, 2013; Odom ve ark., 2005; Test, Kemp-Inman, Diegelmann, Hitt ve Bethune, 2015). Bu aşamadan sonra otizm konusunda çalışmalara ilişkin bulgular bir toblo ile sunulmuştur (Rakap, Birkan ve Kalkan, 2017).

Tablo 1. NAC Tarafindan Belirlenen Otizm Spektrum Bozukluğu Alanında Bilimsel Dayanağı Olan, Umut Vadeden ve Bilimsel Dayanağı Olmayan Uygulamalar (0-22 yaş ve 22 yaş üzeri)

\begin{tabular}{|c|c|c|}
\hline $\begin{array}{l}\text { Bilimsel Dayanağı } \\
\text { Uygulamalar (0-22 yaş) }\end{array}$ & $\begin{array}{l}\text { Umut Vadeden Uygulamalar } \\
\text { (0-22 yaş) }\end{array}$ & $\begin{array}{l}\text { Bilimsel Dayanağı Olmayan } \\
\text { Uygulamalar (0-22 yaş) }\end{array}$ \\
\hline $\begin{array}{l}\text { - Davranışsal Müdahaleler } \\
\text { - Sözel Davranış } \\
\text { - Ayrık Denemelerle Öğretim }\end{array}$ & $\begin{array}{l}\text { - Destekleyici ve Alternatif } \\
\text { İletişim Araçları }\end{array}$ & - Hayvan-Destekli Terapi \\
\hline - Bilişsel Davranışsal Müdahale & - Gelişimsel İlişki Temelli & • İşitsel Bütünleştirme Öğretimi \\
\hline Paketi & Müdahale & \\
\hline - $\quad$ Küçük Çocuklar İçin & - Resim Değiş Tokuşuna & - Gelişimsel/Bireysel \\
\hline Davranışsal & Dayanan İletişim Sistemi & Farklılıklar/İlişki Temelli \\
\hline Müdahale & & Yaklaşım \\
\hline • Dil Öğretimi (Üretim) & - Maruz Birakma Paketi & - Kavram Haritas1 \\
\hline - Model Olma & • İşlevsel İletişim Öğretimi & • Kolaylaştırılmış İletişim \\
\hline $\begin{array}{l}\text { - Doğal Öğretim Stratejileri } \\
\text { • Fırsat Öğretimi }\end{array}$ & • Taklit-Temelli Müdahale & - Gluten-Casein Diyeti \\
\hline - Ebeveyn Eğitim Paketi & • İletişim Başlatma Öğretimi & - Hareket-Temelli Müdahale \\
\hline - Akran Eğitim Paketi & $\begin{array}{l}\text { • Dil Öğretimi (Üretim ve } \\
\text { Anlama) }\end{array}$ & - SENSE Tiyatro Müdahalesi \\
\hline - Temel Tepki Öğretimi & - Masaj Terapisi & - Duyusal Müdahale Paketi \\
\hline
\end{tabular}




\begin{tabular}{|c|c|c|}
\hline - Etkinlik & - Çok-Bileşenli Paket & - Şok Terapisi \\
\hline \multicolumn{3}{|l|}{ Çizelgeleri(Programlar) } \\
\hline \multirow[t]{2}{*}{ - Replikli Öğretim } & • Müzik Terapisi & - Sosyal Davranışsal Öğrenme \\
\hline & & Stratejisi \\
\hline - Kendini Yönetme & - Egzersiz & •Sosyal Düşünme Müdahalesi \\
\hline - Sosyal Beceri Paketi & - Azaltma (Davranış) Paketi & \\
\hline \multirow[t]{6}{*}{ • Öykü Temelli Müdahaleler } & • İşaret Öğretimi & \\
\hline & - Sosyal İletişim Müdahalesi & \\
\hline & - Yapılandırılmış Öğretim & \\
\hline & Teknoloji-Temelli & \\
\hline & Müdahale & \\
\hline & - Zihin Kuramı Öğretimi & \\
\hline Bilimsel $\quad$ Dayanağ1 & Umut Vadeden Uygulamalar & Bilimsel Dayanağ1 Olmayan \\
\hline Uygulamalar (22 yaş üstü) & (22 yaş üstü) & Uygulamalar (22 yaş üstü) \\
\hline \multirow[t]{3}{*}{ Davranışsal Müdahaleler } & - Mesleki Eğitim Paketi & $\begin{array}{l}\text { - Bilişsel Davranışsal Müdahale } \\
\text { Paketi } \\
\text { - Model Olma }\end{array}$ \\
\hline & & • Müzik Terapisi \\
\hline & & - Duyusal Bütünleştirme Paketi \\
\hline
\end{tabular}

Otizm spektrum bozukluğu tedavilerinde alternatif yollara başvurulmaktadır. Son yıllarda Bağırsak mikrobiyotasının merkezi sinir sistemi ile nöroendokrin, nöroimmün ve otonom sinir sistemi aracılığıyla iki yönlü bir ilişki içinde olduğunun gösterilmesiyle nöropsikiyatrik bozukluklarda özellikle de OSB'unda mikrobiyota-bağırsak-beyin ekseni araştırılmaya başlanmıştır (Ersöz Alan ve Gülerman, 2019). Ancak bu çalışmalaırın henüz çok başlangıç aşamasında olduğu ve küçük ölçekli verilere işaret ettiği, bu alanda yapılacak yeni çalsşmalara ihtiyaç olduğu görülmektedir. Yoğun ve uzun süreli uygulamalı davranış analizi müdahalelerin gerek zihinsel süreçte gerekse de sosyal alanda oldukça olumlu etkiler sağladığı bildirilmektedir (Virues-Ortega, 2010). Ancak davranışsal terapiler veya gelişimsel müdahalelerin tüm semptomları ortadan kaldıracağını düşünülmesi doğru olmaz. $\mathrm{Bu}$ tedavilerin yararlı olduğu kabul edilmekle etkilerinin kanıt düzeyinde çalışılmasının zorluğu unutulmamalıdır (Ospina ve ark., 2008).

Geçmiş yıllarda DEHB için farmakolojik olmayan tedavilere ilgi artmaktadır. Bu tür alanyazın en son ve tartışmalı titiz sentezi, son 3 yılda Avrupa DEHB Kılavuzları Grubu (EAGG) tarafından, DEHB için farklı farmakolojik olmayan tedavilerin verimliliğini ele alan diyet müdahalelerini, 
davranışsal müdahaleleri, bilişsel eğitim ve neurofeedback (kişinin kendi beyin dalgalarını değiştirmesine yardımcı olan bir öğrenme stratejisi) içeren bir dizi meta-analiz çalışması gerçekleştirilmiştir. Genel olarak, bu meta-analizler dizisi, tüm bu müdahalelerin etkinliğini (serbest yağ asidi takviyesi için küçük bir etki için olası bir istisna ile) değerlendiricilerin geri bildirimlerine dayanarak çok küçük ve tutarsız anlamlı farklar göstermektedir (Cortese ve ark. 2015; Daley ve ark. 2014). Farmakolojik olmayan müdahalelerin DEHB ile bağlantılı koşullar üzerinde etkili olduğu bulunmuştur. Dikkat eksikliği hiperaktivite bozuklukluğunda kanıtlanmış etkileri ve görece az yan etkileri ile uyarıcılar (psikostümülanlar) olsa da anne babalar bu ilaçların kullanımından ileride madde kullanımı ya da bağımlılığa temel oluşturacağını düşündükleri için kaçınmaktadırlar. Oysaki bu alanda yürütülen bir metaaanaliz çalışması tam tersini iddia etmekte, uyarıcı ilaç kullanımın ileriki yaşlarda madde ya da alkol kötüye kullanımı/bağımlılık riskini azalttığını göstermektedir (Wilens, Faraone, Biederman ve Gunawardene, 2003). Bu nednele ilaç dışındaki uygulamalarda, müdahalelerin bilimsel dayanağı ve etkililiği konusunda önemli bazı kuruluşların öncü çalışmalarının takip edilmesi önerilmektedir. Bunların başında Dikkat Eksikliği Hiperaktivite Bozukluğu Derneği (ADDA), Çocuk ve Ergen Dikkat Eksikliği Hiperkativite Bozukluğu (CHADD), Amerikan Çocuk ve Ergen Psikiyatrisi Akademisi, Ulusal Sağlık ve Klinik Mükemmellik Enstitüsü (NICE), Kanada Dikkat Eksikliği Hiperaktivite Bozukluğu Birliği (CADDRA), Amerikan Çocuk ve Ergen Psikiyatrisi Birliği (AACAP) sayılabilir.

Dikkat Ekslikliği hiperaktivite bozukluğunun ortaya çıkmasında birçok etken bir arada rol oynadığ1 için, kişisel ve kişilerarası alanlarda (okul, aile, akran grupları gibi) soruna neden olan alanlarda çok yönlü birden fazla uzmanlık alanının ortak tedavi yaklaşımı en uygun yol olduğu görülmektedir. $\mathrm{Bu}$ nedenle etkisi kanıtlanmış tek bir eğitim modelinden söz etmek oldukça güç olsa da etkileşimli modellerden söz edilebilir. En etkili bulunan tedavi yöntemlerinin başında aile eğitimleri, sosyal beceri eğitimleri, yönetici işlevlerin düzenlenmesine yönelik eğitimler, çocuklarda oyun tedavisi, yetişkinlerde ise bilişsel ve davranışçı terapi uygulamaları gelmektedir. Bunun ikinci sırada takip eden, umut vadeden ancak sınırlı çalışma olduğu için alanda daha fazla çalışılmasına ihtiyaç duyulduğu bilinen bibliyoterapi, göz hareketleriyle duyarsızlaştırma ve yeniden işlemleme (EMDR) uygulamaları, arttırılmış gerçeklik uygulamaları, nörofeedback yaklaşımı, fizyoterapi ve rehabilitasyon yaklaşımı, ergo terapi, beslenme düzenlenmesi, çocuklarda ve erişkinlerde bilinçli farkındalık yaklaşımı, hayvanlarla etkilişim uygulamaları gelmektedir. Buna ek olarak tanıyı alan kişiye yönelik psikoeğitim uygulamaları, okulda etkin yönetim, PDR servisleri ve özel eğitim yaklaşımı da çok yönlü yaklaşımda eğitici başlıklar arasında yer almaktadır. Dikkat Eksikliği ve Hiperaktivite Bozukluğunun çok yönlü yapısı otizmde olduğu gibi alandaki uygulamalara ilişkin doğrudan bir sınıflamaya imkân tanımasa da bahsedilen uygulamaların dışında kalan, yukarıda 
sayılan kuruluşlar tarafindan onaylanmayan, alanyazında bilimsellikten uzak ve etkili olmayan uygulamalardan korunulması da önem arz etmektedir.

Özetle, Bağlanma ve sosyal davranışlarda rol aldığı bilinen oksitosin hormonunun da etkisi incelenmiş, DEHB ve OSB’unun da içinde bulunduğu pek çok psikiyatrik bozuklukta oksitosin oranının sağlıklı örneklemde farklı olduğu oksitosinin psikiyatrik bozukluklarda iyileştirici etkisinin olduğu tespit edilmiştir (Ishak, Kahloon ve Fakhry, 2011).

\section{SONUÇ}

Her iki bozuklukla ilgili geniş alanyazın nedeniyle, bu gözden geçirme çalışmasında her iki bozukluğun karşılaştırılmasını içeren çalışmalara vurgu yaparak seçilen yönlere odaklanılmak durumunda kalınmıştır. Özellikle genetik ve çevresel risk faktörleri ve bunların aracılık mekanizmaları, tedavi yaklaşımları konusunda örtüssen ve ayırt edici özellikleriyle ile ilgili birkaç açık soru bulunmaktadır. Çalışmamızdaki açık soru bölümüne odaklandığımıda iki bozukluğu aynı anda içeren çalışmaların kısıtlılığı ilk göz çarpan ekslikliktir. Bu yönüyle alanyazında bu iki bozukluğun bir arada yer aldığı çalışamaların gerekliliğine vurgu yapmamız gerekmektedir. İkincil olarak ise uygulamada ve tedavideki yetersizlikler ve kafa karşıklılıklarının giderilmesi önemli görülmektedir.

Alanyazında varolan ve çalışamıza da dâhil edilen, DEHB ve OSB aynı anda ele alan kısıtlı çalışmalarda davranışsal, bilişsel, nörolojik, genetik, sosyal, duygusal ve gelişimsel bulgular değerlendirildiğinde ise, DEHB ve OSB etijolojisindeki benzerliğin, daha önce eş tanıya izin verilmeyen yönü nedeniyle yeterince incelenemedi görülmetedir. Ayrıca eş tanıya işaret eden çalışmaların çoğunun kesitsel yöntemle yapılmış olduğu bunun da alanyazındaki sonuçları kısıtladığı görülmektedir. Bu nedenlerle DEHB ve OSB tanısı DSM-IV’te önerilen şekliyle, nörogelişimsel bozukluklar altında, bir arada ancak ayrı tanıya da izin verecek şekilde, ele alınmaya devam edilmesi, çalışmaların bu bakış açısıyla yürütülmesinin, mevcut verilerde gelişmeye ve hastaya özel tedaviyi planlaması yapılmasına olanak tanıyacağı düşünülmektedir. Ancak özellikle nörolojik bulgular ve klinik gözlemi bütünleştiren çalışmalara daha fazla yer verilmesi gerektiği, katılımcıların homojen dağıldığı, çift-kör, plasebo kontrollü, boylamsal ya da karma desenli çalışmalara ihtiyaç duyulduğu görülmektedir.

Ayrıca uygulama ve araştırma alanı iligilendiren bir bulgu olarak, bu çalışma kapsamında yapılan incelemede alan yazında çocuklar üzerinde yürütülen iki yetersizliğin ilişkisini araştıran çalışmaların, çoğunlukla çocuğun ailesi ile gerçekleştirildiği görülmüştür. Ancak daha geniş kapsamlı ve kanıta dayalı yöntemlerle yürütülecek çalışmaların bu çocukların öğretmenleri, kardeşleri, arkadaşları ile 
yapılmasıyla farklı izlenim ve gözlemlerin birleştirilmesine olanak tanıyacağ1 düşünülmektedir (Akbaş ve ark., 2009). Her iki bozukluk arasındaki ilişkinin eş tanı alabilecek düzeyinde olduğu düşünülürse sürecinin daha verimli bir hale getirilmesi amacıyla OSB, DEHB ve OSB-DEHB eş tanılı bireyleri karşılaştıran kesitsel ve boylamsal çalışmaları birleştiren desenler kullanılabilir. Temel araştırmalardan elde edilen sonuçlar henüz OSB, DEHB ve OSB+DEHB bozuklukları için daha da özellikli ve bireyselleştirilmiş yaklaşımlara dönüştürülmesi gerekmektedir. $\mathrm{Bu}$ alandaki araştırmalar ayrı ayrı ilerliyor gibi görünse de, OSB ve DEHB'nun bir arada olduğu çalışmalar henüz başlangıç aşamasındadır ve daha iyi tanı ve tedavi için bozuklukları veya bozuklukların spesifik alt tiplerini ayırt edebilmek için daha fazla çalışma gereklidir.

Akademik çalışmalarla tanı ve tedaviye yönelik bulguların arttırılmasının yanı sıra, her iki bozukluk için de toplumsal düzeyde de yapılacak uygulamaya yönelik çalışmalar önemli bir diğer adımdır. İlk olarak aileden başlayarak, ailenin psikoeğitim yoluyla bilinçlenirilmesi önerilmektedir. Bu alanda toplumsal farkındalığı arttırmak amacıyla çocukların ve ebeveynlerinin damgalanmasını önlemek için ülke genelinde DEHB ve OSB hakkında halkın bilinçlendirilmesine yönelik seminerler, konferanslar ve bilgilendirme faaliyetleri yapılması önerilmektedir. Her iki bozukluk için de erken tanı oldukça önemlidir. Bu nedenle çocuklar çalışan tüm uzmanların ya da uzaman adaylarının (öğretmenler, hekimler) farkındalık düzeylerinin arttırılması, erken tanı konusunun önemini daha iyi anlayabilmeleri için ilgili tıp ve eğitim kadrosu için bir bilgilendirme kampanyası düzenlenmesi sağlanabilir. Milli Eğitim Bakanlığı ve Yükseköğretim Kurulu işbirliğiyle, öğrencilerle ilgili öğretmen işbirliği arttırlarak mevcut sorunları çözmek için yeni stratejiler ve politikalar belirlenebilir. Özellikle özel eğitim ile desteklenmesinin zorunlu olduğu bilinen OSB tanısı almış çocuklar için sağlanan eğitim ve terapi hizmetlerini ve eğitim saatlerini artırılması ve ücretlerinin düzenlenmesi sağlanabilir. $\mathrm{Bu}$ amaca hizmet edecek şekilde alanda uzman ve eğitimli çalışmacıların atanması amacıyla ilgili bakanlıklar tarafından çeşitli çalışmalar yapılabilir. İlgili kurumların bu çocuklara ve ebeveynlerine geçici bakım vermelerini sağlamak, çocuğun sağlıklı gelişiminin yanı sıra aile düzeninin sağlıklı kardeşlerin ihtiyaçlarının karşılanması konusunda ebeveynlerin daha rahat rol alabilmesini sağlayacağ1 düşünülmektedir.

\section{KAYNAKÇA}

Agha, S.S., Zammit, S., Thapar, A. \& Langley, K. (2013) Are parental ADHD problems associated with a more severe clinical presentation and greater family adversity in children with ADHD?. European Child and Adolescent Psychiatry, 22(6), 369-377.

Akbaş, S., Karabekiroğlu, K., Pazvantoğlu, O. \& Böke, Ö. (2009) Özel eğitim ve ilaç alan otistik bozuklu çocukların otistik belirtiler açısından sekiz haftalık izlemi ve ek tanı özellikleri. Klinike Psikiyatri, 12,134-140. 
American Psychiatric Association (1994). Diagnostic and statistical manual of mental disorders (4. baske). Washington: DC: Author

American Psychiatric Association (2000). Diagnostic and statistical manual of mental disorders (4. baskel/revizyon). Washington: DC: Author

Amerikan Psikiyatri Birliği (2013). Mental Bozuklukların Tanısal ve Sayımsal El Kitabı (DSM-V. (Çev. ed.: E Köroğlu). Ankara: Hekimler Yaym Birliği.

Ames, C. S., \& White, S. J. (2011). Brief report: Are ADHD traits dissociable from the autistic profile? Links between cognition and behaviour. Journal of Autism and Developmental Disorders, 41, 357-363.

Andersen, C. H., Thomsen, P. H., Nohr, E. A. \& Lemcke, S. (2018). Maternal body mass index before pregnancy as a risk factor for ADHD and autism in children. European Child and Adolescent Psychiatry, 27(2), 139-148.

Angell, M. E., Meadan, H., \& Stoner, J. B. (2012). Experiences of siblings of individuals with autism spectrum disorders. Autism Research and Treatment, 2012.

Antshel, K. M., Zhang-James, Y., \& Faraone, S. V. (2013). The comorbidity of ADHD and autism spectrum disorder. Expert Review of Neurotherapeutics, 13(10), 1117-1128.

Asherson, P., \& Image Consortium. (2004). Attention-Deficit Hyperactivity Disorder in the postgenomic era. European Child and Adolescent Psychiatry, 13(1), i50-i70.

Ay, M. G., \& Kılıç, B. G. (2019). Dikkat Eksikliği Hiperaktivite Bozukluğu Olan Ergenlerde Empati ve İlişkili Etmenler. Türk Psikizatri Dergisi, 30(4):260-7.

Banaschewski, T., Becker, K., Scherag, S., Franke, B. \& Coghill, D. (2010). Molecular genetics of attention-deficit/hyperactivity disorder: an overview. European Child Adolescent Psychiatry, 19: $237-257$

Barkley, R. A., Fischer, M., Smallish, L., \& Fletcher, K. (2006). Young adult outcome of hyperactive children: adaptive functioning in major life activities. Journal of the American Academy of Child and Adolescent Psychiatry, 45(2), 192-202.

Briscoe-Smith, A. M. \& Hinshaw, S. P. (2006). Linkages between child abuse and attentiondeficit/hyperactivity disorder in girls: Behavioral and social correlates. Child Abuse and Neglect, 30(11), 1239-1255.

Brunelle, F., Bargiacchi, A., Chabane, N., Saitovitch, A., Grévent, D., Zilbovicius, M., \& Boddaert, N. (2012). Brain imaging of infantile autism. Archives de pediatrie: organe officiel de la Societe francaise de pediatrie, 19(5), 547-550.

Bulut, H. (2016). Dikkat eksikliği ve hiperaktivite bozukluğu olan çocuklarda, nöroplastisite ve nöroprotektif sürẹclerin incelenmesi. (Yayınlanmamış yüksek lisans tezi) Batman Üniversitesi, Batman.

Christensen, D. L., Braun, K. V. N., Baio, J., Bilder, D., Charles, J., Constantino, J. N., ... \& Lee, L. C. (2018). Prevalence and characteristics of autism spectrum disorder among children aged 
8 years-autism and developmental disabilities monitoring network, 11 sites, United States, 2012. MMWR Surveillance Summaries, 65(13), 1.

Cook, B. G., ve Cook, S. C. (2013). Unraveling evidence-based practices in special education. The Journal of Special Education, 47(2), 71-82

Cortese, S., Ferrin, M., Brandeis, D., Buitelaar, J., Daley, D., Dittmann, R. W., ... \& Zuddas, A. (2015). Cognitive training for attention-deficit/hyperactivity disorder: meta-analysis of clinical and neuropsychological outcomes from randomized controlled trials. Journal of the American Academy of Child and Adolescent Psychiatry, 54(3), 164-174.

Cortese, S. (2016). Attention-Deficit Hyperactivity Disorder and Autism Spectrum Disorder. In Psychiatric Symptoms and Comorbidities in Autism Spectrum Disorder (pp. 79-91). Springer, Cham.

Crane, L., Goddard, L., \& Pring, L. (2009). Specific and general autobiographical knowledge in adults with autism spectrum disorders: The role of personal goals. Memory, 17(5), 557-576.

Çetin, F. H., \& Işık, Y. (2018). Dikkat Eksikliği Hiperaktivite Bozukluğu ve Genetik. Psikizyatride Guncel Yaklasimlar, 10(1), 19-39.

Daley, D., Jones, K., Hutchings, J., \& Thompson, M. (2009). Attention deficit hyperactivity disorder in pre-school children: current findings, recommended interventions and future directions. Child: Care, Health and Development, 35(6), 754-766.

Daley D, Van der Oord S, Ferrin M, Danckaerts M, Doepfner M. \& Cortese, S.(2014) Behavioral interventions in attention-defi cit/hyperactivity disorder: a meta-analysis of randomized controlled trials across multiple outcome domains. Journal of the American Academy of Child and Adolescent Psychiatry, 53: 835-847.

Davidovitch, M., Glick, L., Holtzman, G., Tirosh, E., \& Safir, M. P. (2000). Developmental regression in autism: maternal perception. Journal of Autism and Developmental Disorders, 30(2), 113-119.

Davies, W. (2014). Sex differences in attention deficit hyperactivity disorder: candidate genetic and endocrine mechanisms. Frontiers in Neuroendocrinology, 35(3), 331-346.

Dougherty, C. C., Evans, D. W., Myers, S. M., Moore, G. J., \& Michael, A. M. (2016). A comparison of structural brain imaging findings in autism spectrum disorder and attention-deficit hyperactivity disorder. Neuropsychology Review, 26(1), 25-43.

Dunn, D. W., Austin, J. K., Harezlak, J., \& Ambrosius, W. T. (2003). ADHD and epilepsy in childhood. Developmental Medicine and Child Neurology, 45(1), 50-54.

Ellis, L. C., Berg-Nielsen, T. S., Lydersen, S., \& Wichstrøm, L. (2012). Smoking during pregnancy and psychiatric disorders in preschoolers. European Child and Adolescent Psychiatry, 21(11), 635-644.

Ercan, E.S. (2010) Dikkat eksikliği hiperaktivite bozukluğunda epidemiyolojik veriler. Turkiye Klinikleri Journal of Pediatric Sciences, 6:1-5. 
Erdoğan, H., Kelten, B., Akdemir, O., Karaoğlan, A. \& Taşdemiroğlu, E. (2013). Otizm ve serebellar mutizm: nöroanatomik bulguların bir derlemesi / Autism and cerebellar mutism: a review of the neuroanatomical findings. Maltepe Trp Dergisi. 5(2), s. 57-65.

Ersöz Alan, B., \& Gülerman, F. (2019). Otizm Spektrum Bozukluğunda Bağırsak Mikrobiyotasının Rolü. Turkish Journal of Psychiatry, 30(3):210-9.

Faraone, S.V. (2006) Advances in the genetics and neurobiology of attention deficit hyperactivity disorder. Biological Psychiatry; 60:1025-1027.

Fombonne, E. (2009). Epidemiology of pervasive developmental disorders. Pediatric Research, 65(6), 591.

Eyüboğlu, M., \& Eyüboğlu, D. (2018). Suça Sürüklenen Çocuklarda Psikiyatrik Bozukluklar, Sosyodemografik Özellikler ve Risk Faktörleri. Klinik Psikiyatri Dergisi, 21(1).

Faraone, S. V., \& Buitelaar, J. (2010). Comparing the efficacy of stimulants for ADHD in children and adolescents using meta-analysis. European Child and Adolescent Psychiatry, 19(4), 353-364.

Gargaro, B. A., May, T., Tonge, B. J., Sheppard, D. M., Bradshaw, J. L., \& Rinehart, N. J. (2018). Attentional Mechanisms in Autism, ADHD, and Autism-ADHD Using a Local-Global Paradigm. Journal of Attention Disorders, 22(14), 1320-1332.

General Prevalence of ADHD (CHADD). DEHB'nin Genel Yaygınlı̆̆1 (2020, 16 Ocak). Erişim adresi: https://chadd.org/about-adhd/general-prevalence/

Ghanizadeh, A. (2013). Atomoxetine for treating ADHD symptoms in autism: a systematic review. Journal of Attention Disorders, 17(8), 635-640.

Gillespie-Lynch, K., Sepeta, L., Wang, Y., Marshall, S., Gomez, L., Sigman, M., \& Hutman, T. (2012). Early childhood predictors of the social competence of adults with autism. Journal of Autism and Developmental Disorders, 42(2), 161-174.

Girli, A., Özgönenel, S. Ö., Sarı, H. Y., \& Ardahan, E. (2016). Otizmi olan çocukların beslenme durumunun değerlendirilmesi. Çocuk ve Medeniyet Dergisi, 1(1).

Gurrieri, F. (2012). Working up autism: the practical role of medical genetics. In American Journal of Medical Genetics Part C: Seminars in Medical Genetics (Vol. 160, No. 2, pp. 104-110). Hoboken: Wiley Subscription Services, Inc., A Wiley Company.

Gustavson, K., Ystrom. E., Stoltenberg. C., Susser. E., Surén. P., \& Magnus P. (2017). Smoking in pregnancy and child ADHD. Pediatrics, 139:e20162509.

Gül, H., ve Öncü, B. (2018). Dikkat Eksikliği Hiperaktivite Bozukluğunun Etyolojisinde Çevresel Etkenler. Psikiyatride Guncel Yaklasimlar, 10(2), 138-175.

Hart, H., Radua, J., Nakao, T., Mataix-Cols, D., \& Rubia, K. (2013). Meta-analysis of functional magnetic resonance imaging studies of inhibition and attention in attentiondeficit/hyperactivity disorder: exploring task-specific, stimulant medication, and age effects. JAMA psychiatry, 70(2), 185-198. 
IsHak, W. W., Kahloon, M., \& Fakhry, H. (2011). Oxytocin role in enhancing well-being: a literature review. Journal of Affective Disorders, 130(1-2), 1-9.

Joshi, G., Wozniak, J., Petty, C., Martelon, M. K., Fried, R., Bolfek, A., \& Caruso, J. (2013). Psychiatric comorbidity and functioning in a clinically referred population of adults with autism spectrum disorders: a comparative study. Journal of Autism and Developmental Disorders, 43(6), 1314-1325.

Kara, K., Durukan, İ., Koparan, C., Altun, D., Karaman, D., \& Özkan, S. (2016). Dikkat eksikliği hiperaktivite bozukluğu olan çocukların anne-babalarının öfke ve saldırganlık düzeyleri. Anadolu Psikiyatri Dergisi, 17(3).

Karabekiroğlu, K., Cakin-Memik, N., Ozcan-Ozel, O., Toros, F., Öztop, D., Özbaran, B., \& Aydın10, C. (2009). DEHB ve Otizm ile İlgili Bilgi Düzeyleri ve Damgalama: Sinıf Öğretmenleri ve Anababalarla Çok Merkezli Bir Çalssma. Klinik Psikìyatri, 12, 79-89.

Kurnaz, S. (2017). MOXO d-CPT DEHB testi çocuk versiyonunun dikkat eksikliği ve biperaktivite bozukluğunda değerlendirme arac olarak kullanulması. (Yayımlanmamış yüksek lisans tezi) İstanbul Ticaret Üniversitesi, İstanbul.

Kim, Y. S., Leventhal, B. L., Koh, Y. J., Fombonne, E., Laska, E., Lim, E. C., \& Song, D. H. (2011). Prevalence of autism spectrum disorders in a total population sample. American Journal of Psychiatry, 168(9), 904-912.

Kondolot, M., Özmert, E., Öztop, D., Mazıcıŏglu, M., Gümüş, H. \& Elmalı, F. (2016). The modified checklist for autism in Turkish toddlers: A different cultural adaptation sample. Research in Autism Spectrum Disorders, 21:121-127.

Kültür, S. E. C.., \& Öztekin, C. (2017). Dikkat Eksikliği/Hiperaktivite Bozukluğu ve Yıkıcı Davranış Sorunlarının Tedavisinde Anne-Babalık Becerileri. Turkiye Klinikleri Journal, 3(2), 106-14.

Leonard, M. A., Milich, R., \& Lorch, E. P. (2011). The role of pragmatic language use in mediating the relation between hyperactivity and inattention and social skills problems. Journal of Speech, Language, and Hearing Research, 54, 567-579.

İbrahim, S. H., Voigt, R. G., Katusic, S. K., Weaver, A. L., \& Barbaresi, W. J. (2009). Incidence of gastrointestinal symptoms in children: A population-based study. Pediatrics, 124(2), 680.

Kerimoğlu, E., Kılıç, B.G., Gürkan, C.K., \& Öztürk, M. (2008) Çocukluk ve Ergenlikte Sık Görülen Ruhsal Bozukluklar. Edt. Öztürk O, Uluşahin A. İçinde: Ruh Sağllğı ve Bozuklukları -2. Cilt, 11. Baskı, Ankara: Nobel Tip Kitapevi; p.744.

Kılınçaslan, A., Motavalı Mukaddes, N., Sözen Küçükyazıcı, G., \& Gürvit, H. (2010). Asperger Bozukluğu olgularında yürütücü işlevler ve dikkatin değerlendirilmesi. Türk Psikiyatri Dergisi, 21, 289-299.

Korkmaz, B. (2001). Otizm: Başlıca davranış sorunları ve pratik yaklaşım. Yeni Symposium 39, 1, 2634. 
Kovess, V., Keyes, K. M., Hamilton, A., Pez, O., Bitfoi, A., Koç, C., \& Otten, R. (2015). Maternal smoking and offspring inattention and hyperactivity: results from a cross-national European survey. European Child and Adolescent Psychiatry, 24(8), 919-929.

Lee, S. H., Ripke, S., Neale, B. M., Faraone, S. V., Purcell, S. M., Perlis, R. H., \& Absher, D. (2013). Genetic relationship between five psychiatric disorders estimated from genome-wide SNPs. Nature Genetics, 45(9), 984.

Maia, C. R. M., Cortese, S., Caye, A., Deakin, T. K., Polanczyk, G. V., Polanczyk, C. A., \& Rohde, L. A. P. (2017). Long-term efficacy of methylphenidate immediate-release for the treatment of childhood ADHD: a systematic review and meta-analysis. Journal of Attention Disorders, 21(1), 3-13.

Mannuzza, S., \& Klein, R. G. (2000). Long-term prognosis in attention-deficit/hyperactivity disorder. Child and Adolescent Psychiatric Clinics, 9(3), 711-726..

McGovern, C. W., \& Sigman, M. (2005). Continuity and change from early childhood to adolescence in autism. Journal of Child Psychology and Psychiatry, 46(4), 401-408.

Mire, S. S., Raff, N. S., Brewton, C. M., \& Goin-Kochel, R. P. (2015). Age-related trends in treatment use for children with autism spectrum disorder. Research in Autism Spectrum Disorders, 15, 29-41.

Mulligan, A., Anney, R. J., O’Regan, M., Chen, W., Butler, L., Fitzgerald, M., \& Nijmeijer, J. (2009). Autism symptoms in attention-deficit/hyperactivity disorder: a familial trait which correlates with conduct, oppositional defiant, language and motor disorders. Journal of Autism and Developmental Disorders, 39(2), 197-209.

Naaijen, J., Bralten, J., Poelmans, G., Faraone, S., Asherson, P., Banaschewski, T., \& Miranda, A. (2017). Glutamatergic and GABAergic gene sets in attention-deficit/hyperactivity disorder: association to overlapping traits in ADHD and autism. Translational Psychiatry, 7(1).

Odom, S. L., Brantlinger, E., Gersten, R., Horner, R. H., Thompson, B., \& Harris, K. R. (2005). Research in special education: scientific methods and evidence-based practices. Exceptional Children, 71, 137-148.

Ospina, M. B., Seida, J. K., Clark, B., Karkhaneh, M., Hartling, L., Tjosvold, L., \& Smith, V. (2008). Behavioural and developmental interventions for autism spectrum disorder: a clinical systematic review. PloS one, 3(11), e3755.

Özeren, G. S. (2013). Otistik spektrum bozukluğu (OSB) ve hastalığa kanıt penceresinden bakış. Acıbadem Üniversitesi Sağllk Bilimleri Dergisi, 4, 57-63.

Ozturk, M. O. (2015). Ruh Sağlığ1 ve Bozuklukları. 13. basım, Ankara: Nobel Tip Kitapevleri, 297326.

Palmer, R. H., Bidwell, L. C., Heath, A. C., Brick, L. A., Madden, P. A., \& Knopik, V. S. (2016). Effects of maternal smoking during pregnancy on offspring externalizing problems: contextual effects in a sample of female twins. Behavior Genetics, 46(3), 403-415. 
Parisi, P., Moavero, R., Verrotti, A. \& Curatolo, P (2010) Attention deficit hyperactivity disorder in children with epilepsy. Brain Development, 32:10-16.

Pazvantoğlu, O., Güneş, S., Karabekiroğlu, K., Yeğin, Z., Sarısoy, G., Korkmaz, I. Z.,. \& Şahin, A. R. (2012). The relationship between ADHD and norepinephrine transporter gene polymorphism in a genetically loaded population. Klinik Psikofarmakol Bülteni, 22(1), 145.

Pelc, K., Kornreich, C., Foisy, M. L. \& Dan, B. (2006). Recognition of emotional facial expressions in attention-deficit hyperactivity disorder. Pediatric Neurology, 35(2), 93-97.

Pliszka, S., \& AACAP Work Group on Quality Issues. (2007). Practice parameter for the assessment and treatment of children and adolescents with attention-deficit/hyperactivity disorder. Journal of the American Academy of Child and Adolescent Psychiatry, 46(7), 894-921.

Polanczyk, G. V., Willcutt, E. G., Salum, G. A., Kieling, C., \& Rohde, L. A. (2014). ADHD prevalence estimates across three decades: an updated systematic review and metaregression analysis. International Journal of Epidemiology, 43(2), 434-442.

Proal, E., Gonzalez-Olvera, J., Blancas, Á. S., Chalita, P. J., \& Castellanos, F. X. (2013). Neurobiology of autism and attention deficit hyperactivity disorder by means of neuroimaging techniques: convergences and divergences. Revista de Neurologia, $57(0$ 1), S16375 .

Rakap, S., Birkan, B., \& Kalkan, S. (2017). Türkiye'de otizm spektrum boұnkluğu ve özel eğitim. Tohum Otizm Vakfi.

Rapport, L. J., Friedman, S. L., Tzelepis, A., \& Van Voorhis, A. (2002). Experienced emotion and affect recognition in adult attention-deficit hyperactivity disorder. Neuropsychology, 16(1), 102.

Rao, P. A., \& Landa, R. J. (2014). Association between severity of behavioral phenotype and comorbid attention deficit hyperactivity disorder symptoms in children with autism spectrum disorders. Autism, 18(3), 272-280.

Reichow, B. (2016). Evidence-based practice in the context of early childhood special education. In B. Reichow, B. A. Boyd, E. E. Barton, \& S. L. Odom (Eds.), Handbook of early childhood special education (pp. 107-124). New York, NY: Springer.

Reichow, B., Volkmar, F. R., \& Bloch, M. H. (2013). Systematic review and meta-analysis of pharmacological treatment of the symptoms of attention-deficit/hyperactivity disorder in children with pervasive developmental disorders. Journal of Autism and Developmental Disorders, 43(10), 2435-2441.

Reiersen, A. M., Constantino, J. N., Grimmer, M., Martin, N. G., \& Todd, R. D. (2008). Evidence for shared genetic influences on self-reported ADHD and autistic symptoms in young adult Australian twins. Twin Research and Human Genetics, 11(6), 579-585.

Rice, F., \& Thapar, A. (2010). Estimating the relative contributions of maternal genetic, paternal genetic and intrauterine factors to offspring birth weight and head circumference. Early Human Development, 86(7), 425-432. 
Sarohan, A. (2017). Acil servise ev kazasi ile gelen hastalarda dikkat eksikliği ve hiperaktivite bozukluğu ilişkisinin değerlendirilmesi. (Yayınlanmamış yüksek lisans tezi). Pamukkale Üniversitesi Tıp Fakültesi, Denizli.

Sarver, D. E., McCart, M. R., Sheidow, A. J., \& Letourneau, E. J. (2014). ADHD and risky sexual behavior in adolescents: Conduct problems and substance use as mediators of risk. Journal of Child Psychology and Psychiatry, 55(12), 1345-1353.

Say, G. N., Karabekiroğlu, K., Babadağı, Z., \& Yüce, M. (2016). Maternal stress and perinatal features in autism and attention deficit/hyperactivity disorder. Pediatrics International, 58(4), 265-269.

Schwartz, S., \& Correll, C. U. (2014). Efficacy and safety of atomoxetine in children and adolescents with attention-deficit/hyperactivity disorder: results from a comprehensive meta-analysis and metaregression. Journal of the American Academy of Child and Adolescent Psychiatry, 53(2), 174-187.

Sciberras, E., Mulraney, M., Silva, D., \& Coghill, D. (2017). Prenatal risk factors and the etiology of ADHD—review of existing evidence. Current Psychiatry Reports, 19(1), 1.

Smalley, S. L., Kustanovich, V., Minassian, S. L., Stone, J. L., Ogdie, M. N., \& McGough, J. J. (2002). Genetic linkage of attention-deficit/hyperactivity disorder on chromosome 16p13, in a region implicated in autism. American Journal of Human Genetics, 71, 959-963.

Sinzig, J., Walter, D., \& Doepfner, M. (2009). Attention deficit/ hyperactivity disorder in children and adolescents with autism spectrum disorder: Symptom or syndrome? Journal of Attention Disorders, 13, 117-126. doi:10.1177/ 1087054708326261.

Solanto, M. V. (2002). Dopamine dysfunction in AD/HD: integrating clinical and basic neuroscience research. Behavioural Brain Research, 130(1-2), 65-71.

Sonuga-Barke, E. J., \& Halperin, J. M. (2010). Developmental phenotypes and causal pathways in attention deficit/hyperactivity disorder: potential targets for early intervention?. Journal of Child Psychology and Psychiatry, 51(4), 368-389.

Shattuck, P. T., Seltzer, M. M., Greenberg, J. S., Orsmond, G. I., Bolt, D., Kring, S., \& Lord, C. (2007). Change in autism symptoms and maladaptive behaviors in adolescents and adults with an autism spectrum disorder. Journal of Autism and Developmental Disorders, 37(9), 17351747.

Shinnar, S., Rapin, I., Arnold, S., Tuchman, R. F., Shulman, L., Ballaban-Gil, K.,. \& Volkmar, F. R. (2001). Language regression in childhood. Pediatric Neurology, 24(3), 185-191.

Sürücü, Ö. (2016). Dikkateksikliği hiperaktivite bozukluğu (DEHB) anne baba-ögretmen elkitabı (2. Bask1). Ankara: Bilgi Yayınevi.

Şan, E., Köse, S., Özbaran, B., Bildik, T. \& Aydin, C. (2018). DEHB'li ergenlerde toplumsal biliş ve duygu düzenleme. Anadolu Psikiyatri Dergisi, 19(1). 
Tatar, Z. B., Yargıç, İ., Oflaz, S. \& Büyükgök, D. (2015). Erişkin dikkat eksikliği hiperaktivite bozukluğunda duygu tanımanın dikkat ve dürtüsellik belirtileri ile ilișkisi. Türk Psikìatri Dergisi, 26: 172, 180.

Test, D. W., Kemp-Inman, A., Diegelmann, K., Hitt, S. B. \& Bethune, L. (2015). Are online sources for 1dentifying evidence-based practices trustworthy?. Exceptional Children, 82(1), 58-80.

Torres, A. R., Whitney, J., \& Gonzalez-Heydrich, J. (2008). Attention-deficit/hyperactivity disorder in pediatric patients with epilepsy: review of pharmacological treatment. Epilepsy and Behavior, 12(2), 217-233.

Tuchman, R., Cuccaro, M., \& Alessandri, M. (2010). Autism and epilepsy: historical perspective. Brain and Development, 32(9), 709-718.

Tuğlu C., \& Şahin Ö.Ö. (2010). Erişkin Dikkat Eksikliği Hiperaktivite Bozukluğu: Nörobiyoloji, Tanı Sorunları ve Klinik Özellikler. Psikiyatride Güncel Yaklaşımlar, 2(1):75116.

Vargas, D. L., Nascimbene, C., Krishnan, C., Zimmerman, A. W., \& Pardo, C. A. (2005). Neuroglial activation and neuroinflammation in the brain of patients with autism. Annals of Neurology: Official Journal of the American Neurological Association and the Child Neurology Society, 57(1), 67-81.

Williams, L. M., Hermens, D. F., Palmer, D., Kohn, M., Clarke, S., Keage, H., \& Gordon, E. (2008). Misinterpreting emotional expressions in attention-deficit/hyperactivity disorder: evidence for a neural marker and stimulant effects. Biological Psychiatry, 63(10), 917-926.

Wilens, T. E., Faraone, S. V., Biederman, J. \& Gunawardene, S. (2003). Does stimulant therapy of attention-deficit/hyperactivity disorder beget later substance abuse? A meta-analytic review of the literature. Pediatrics, 111(1), 179-185.

World Health Organization (2020). General Prevalance of ADHD. 16.01.20 tarihinde https://chadd.org/about-adhd/general-prevalence/ adersinden erişildi.

Yolton, K., Cornelius, M., Ornoy, A., McGough, J., Makris, S., \& Schantz, S. (2014). Exposure to neurotoxicants and the development of attention deficit hyperactivity disorder and its related behaviors in childhood. Neurotoxicology and teratology, 44, 30-45.

Zafeiriou, D. I., Ververi, A., Dafoulis, V., Kalyva, E., \& Vargiami, E. (2013). Autism spectrum disorders: the quest for genetic syndromes. American Journal of Medical Genetics Part B: Neuropsychiatric Genetics, 162(4), 327-366.

Zhang-James, Y., Vaudel, M., Mjaavatten, O., Berven, F. S., Haavik, J., \& Faraone, S. V. (2019). Effect of disease-associated SLC9A9 mutations on protein-protein interaction networks: implications for molecular mechanisms for ADHD and autism. Attention Deficit and Hyperactivity Disorders, 11(1), 91-105.

Zhou, K., Dempfle, A., Arcos-Burgos, M., Bakker, S. C., Banaschewski, T., Biederman, J., \& Ekholm, J. (2008). Meta-analysis of genome-wide linkage scans of attention deficit hyperactivity disorder. American Journal of Medical Genetics Part B: Neuropsychiatric Genetics, 147(8), 1392-1398. 